\title{
Summary Appraisals of the Nation's Ground-Water Resources - Caribbean Region
}

GEOLOGICALS URVEY PROFESSIONALPAPER 813 - U
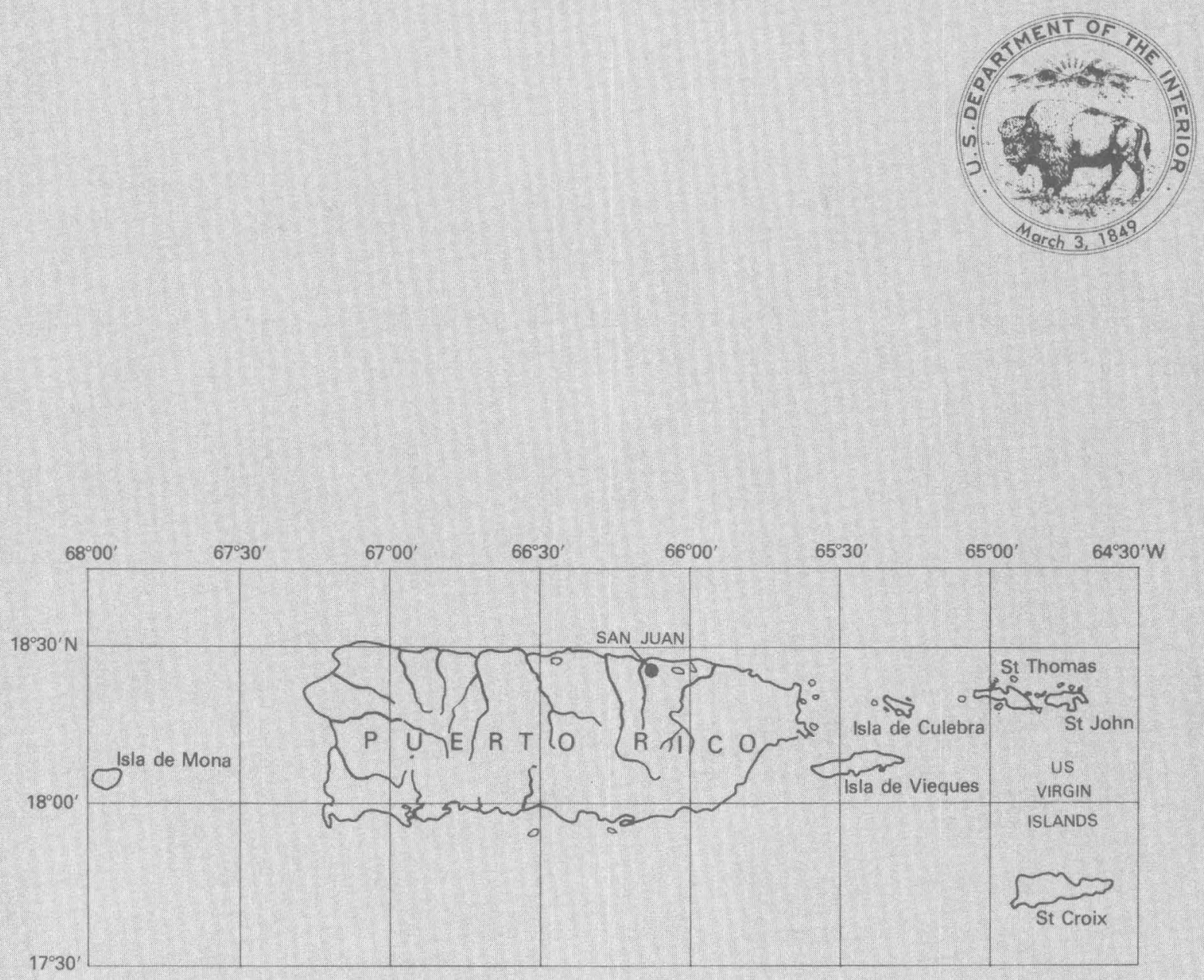

SUMMARY APPRAISALS OF THE NATION'S GROUND-WATER RESOURCESCARIBBEAN REGION 


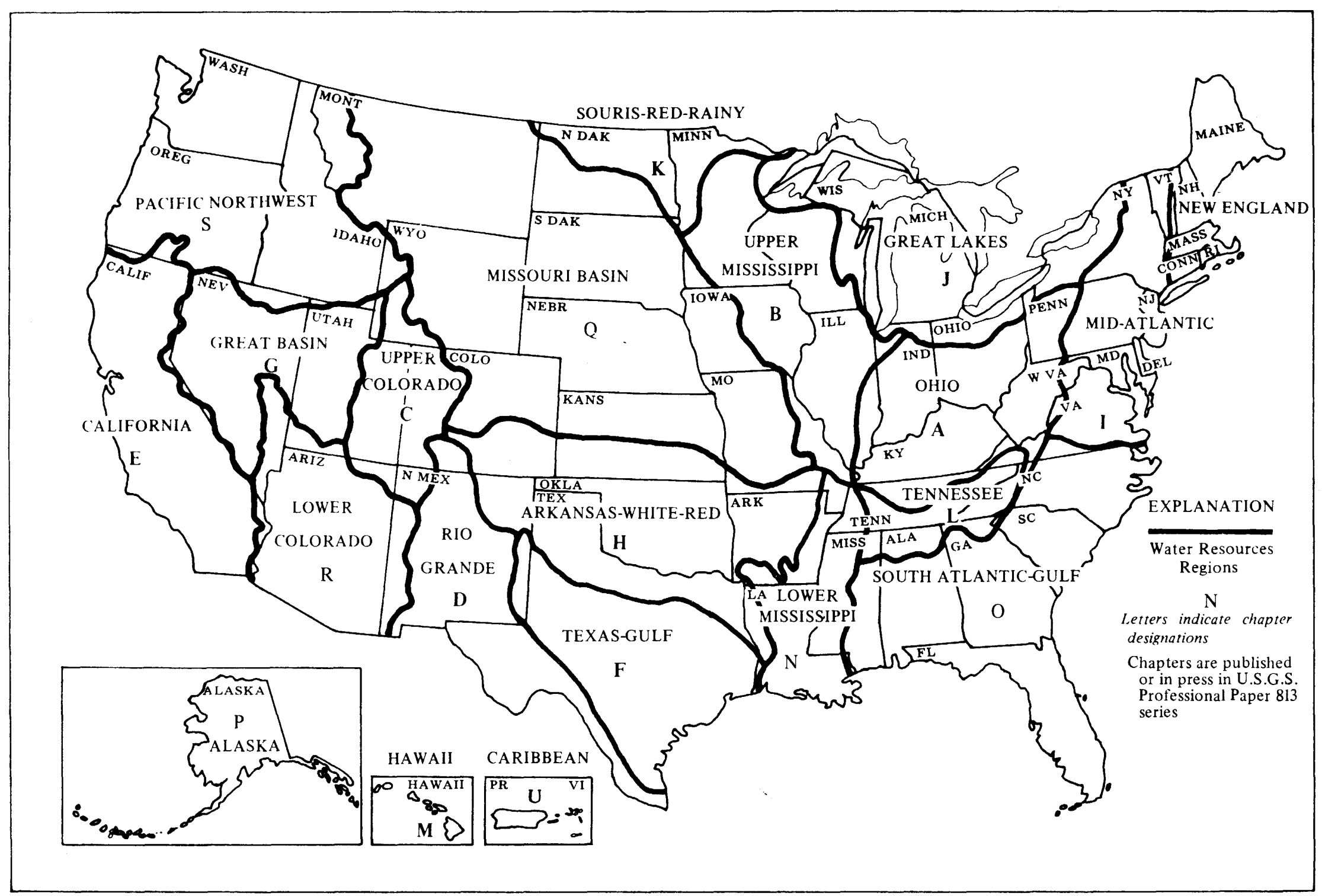

Geographic Index to the Series, U.S. Geological Survey Professional Paper 813, Summary Appraisals of the Nations Ground-Water Resources. Boundaries shown are those established by the United States Water-Resources Council for Water-Resources Regions in the United States. 


\section{Summary Appraisals of the Nation's Ground-Water Resources - Caribbean Region}

By FERNANDO GÓMEZ-GÓMEZ and JAMES E. HEISEL

GEOLOGICAL SURVEY PROFESSIONALAAPER 813 - U

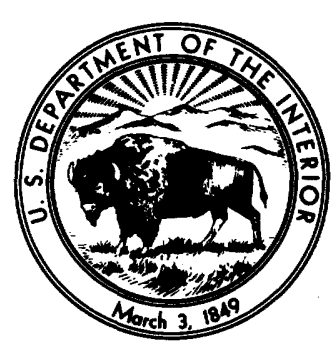




\section{UNITED STATES DEPARTMENT OF THE INTERIOR

\author{
CECIL D. ANDRUS, Secretary
}

\section{GEOLOGICAL SURVEY}

H. William Menard, Director

\section{Library of Congress Cataloging in Publication Data}

Gómez-Gómez, Fernando.

Summary, appraisals of the Nation's ground-water resources-Caribbean region.

(Geological Survey professional paper ; 813-U)

Bibliography: $p$.

1. Water, Underground-Puerto Rico. 2. Water, Underground-Virgin Islands of the United States. I. Heisel, J. E., joint author. II. Title. III. Series: United States. Geological Survey. Professional paper ; 813-U. GB1055.G65 553.7'9'097295 $\quad 80-607817$

For sale by the Superintendent of Documents, U.S. Government Printing Office Washington, D.C. 20402 


\section{CONTENTS}

Abstract

Introduction

General description of the Caribbean Region

Areal extent

Sociopolitical and economic setting

Climate

Geology and hydrogeology

Ground-water provinces, Puerto Rico

North Coast province

South Coast province

Pattillas to Ponce area

Tallaboa-Guayanilla-Yauco-Guanica area

Lajas Valley

West Coast province

East Coast province

Fajardo area

Naguabo-Humacao area

Yabucoa area

Maunabo area

Interior province

Water quality

Puerto Rico's offshore islands

Vieques

Culebra

Mona
Page

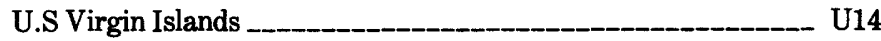

St. Croix _-_ 14

St. Thomas and St. John _- 14

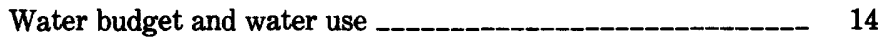

Problems affecting use of water resources _______________ 21

Management-Puerto Rico $\quad 21$

Management-U.S. Virgin Islands _________________-_ 22

Water rights _-____ 22

Practices detrimental to ground-water quality ___________ $\quad 23$

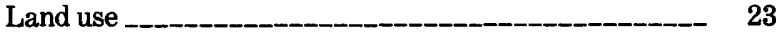

Irrigation practices __________ 24

Optimization of use of water resources __________-_-_ $\quad 25$

Conjunctive use of surface- and ground-water sources ____- $\quad 25$ Reservoir management

Augmenting natural recharge _______________ 25

Ground-water salvage ___________________-_ $\quad 26$

Ground-water mining 27

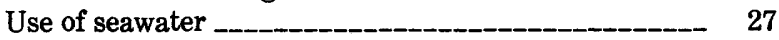

Conservation -28

Water reuse _-_-_-_ 28

Reducing contamination (subsurface storage) _-_____- $\quad 29$

Information deficiencies ___________________-_ 29

Summary -____ $\quad 30$

Selected references ________ 31

\section{ILLUSTRATIONS}

Plates 1, 2. Hydrologic maps showing:

1. Ground-water levels and chloride concentrations of water from selected wells, South Coast province for February 1968 and February 1976

2. Areas of seawater intrusion and zones containing water having total dissolved solids greater than $2,000 \mathrm{mg} / \mathrm{L}$, for Puerto Rico the U.S. Virgin Islands

FIGURE 1. Map showing location, areal extent, and urban areas of the Caribbean Region

2. Graphs showing population trends and projections and economic growth (gross product) for Puerto Rico and for the U.S. Virgin Islands

3, 4. Maps showing:

3. Average annual precipitation, Puerto Rico

4. Caribbean Region, with graphs of mean-monthly long-term rainfall and annual pan evaporation

5, 6. Graphs showing:

5. Ten-year moving averages of rainfall at San Juan, Cayey, and Aguirre, P.R

6. Potential and actual evaporation and their ratio as a function of rainfall

ps showing:

7. General geology of Puerto Rico and its offshore islands

8. Ground-water provinces and their yield to wells in Puerto Rico

9. Graph showing head of selected wells tapping the artesian aquifers of the North Coast province

10. Map showing major alluvial fans of the South Coast province

11. Diagram showing water classification for ground water of Puerto Rico

12-14. Maps showing generalized geology of the U.S. Virgin Islands:

12. St. Croix

13. St. Thomas

14. St. John 
FIGURES 15-17. Graphs showing: Page

15, 16. Generalized water budget for:

15. Puerto Rico and its offshore islands

16. The U.S. Virgin Islands

17. Water-use estimates and projections for Puerto Rico and for the U.S. Virgin Islands ________- 20

18. Maps showing solid-waste disposal sites in the Caribbean Region _-_

19. Diagram showing water classification of wells on the south coast of Puerto Rico

\section{TABLES}

TABLE 1. Ground water in storage in Puerto Rico (by province) and its offshore islands (Vieques, Culebra, and Mona Islands) and in the U.S. Virgin Islands

2. Ground-water flow of part of the North Coast limestones

3. Range in dissolved-solids concentration for ground water in Puerto Rico

4. Water budget for Puerto Rico (by province) and its offshore islands (Vieques, Culebra, and Mona Islands) and for the U.S. Virgin Islands, 1975

\section{FACTORS FOR CONVERTING INTERNATIONAL SYSTEM (SI) UNITS TO INCH-POUND UNITS}

Multiply SI units
millimeter $(\mathrm{mm})$
meter $(\mathrm{m})$
kilometer $(\mathrm{km})$
square meter $\left(\mathrm{m}^{2}\right)$
square kilometer $\left(\mathrm{km}^{2}\right)$
hectare $(\mathrm{ha})$
cubic centimeter $\left(\mathrm{cm}^{3}\right)$
liter $(\mathrm{L})$
cubic meter $\left(\mathrm{m}^{3}\right)$
cubic hectometer $\left.(\mathrm{hm})^{3}\right)$
gram $(\mathrm{g})$
kilogram $(\mathrm{kg})$
degree Celsius $\left({ }^{\circ} \mathrm{C}\right)$
cubic meter per second $\left(\mathrm{m}^{3} / \mathrm{s}\right)$
liter per second $(\mathrm{L} / \mathrm{s})$
liter per second $(\mathrm{L} / \mathrm{s})$

\section{By \\ Length \\ 0.03937 \\ 3.281 \\ 0.621 \\ Area \\ 10.76 \\ 0.386 \\ 2.47 \\ Volume \\ 0.061 \\ 1.06 \\ 35.32 \\ 810.7 \\ Weight \\ 0.035}

2.203

Temperature

$\left(\left(1.8 \times{ }^{\circ} \mathrm{C}\right)+32\right)$

Specific Combinations

35.3

0.0353

15.85
To obtain inch-pound units

inch (in)

foot (ft)

mile (mi)

square foot $\left(\mathrm{ft}^{2}\right)$

square mile $\left(\mathrm{mi}^{2}\right)$

acre

cubic inch $\left(\mathrm{in}^{3}\right)$

quart (qt)

cubic foot $\left(\mathrm{ft}^{3}\right)$

acre foot (acre-ft)

ounce, avoirdupois (oz avdp) pound, avoirdupois ( $1 \mathrm{~b}$ avdp)

degree Fahrenheit $\left({ }^{\circ} \mathrm{F}\right)$

cubic foot per second ( $\left.\mathrm{ft}^{3} / \mathrm{s}\right)$

cubic foot per second $\left(\mathrm{ft}^{3} / \mathrm{s}\right)$

gallon per minute (gal/min) 


\title{
SUMMARY APPRAISALS OF THE NATION'S GROUND-WATER RESOURCES-CARIBBEAN REGION
}

\author{
By FERNANDo GómEZ-GómEZ and JAMES E.HEISEL
}

\section{ABSTRACT}

The Caribbean Region consists of the Commonwealth of Puerto Rico $\left(8,990 \mathrm{~km}^{2}\right.$ (square kilometers)) and the U.S. Virgin Islands $\left(350 \mathrm{~km}^{2}\right)$. The mean annual precipitation varies locally from a high of $5,000 \mathrm{~mm}$ (millimeters) to a low of $730 \mathrm{~mm}$. Maximum precipitation occurs within the peaks of Sierra de Luquillo, and minimum precipitation occurs along the windward parts of the smaller islands and in southwestern Puerto Rico, which lies in a rain shadow. The annual average precipitation is $1,800 \mathrm{~mm}$ in Puerto Rico and $1,061 \mathrm{~mm}$ in the U.S. Virgin Islands. Of this amount $1,130 \mathrm{~mm}$ in Puerto Rico and $990 \mathrm{~mm}$ in the U.S. Virgin Islands are lost to evapotranspiration.

Aquifers constitute a valuable resource in the Caribbean Region. In Puerto Rico, ground-water withdrawals supply about 38 percent of the total water requirements, whereas in the U.S. Virgin Islands they supply 10 percent. Of the ground-water withdrawal of $350 \mathrm{hm}^{3} / \mathrm{yr}$ (cubic hectometers per year) in Puerto Rico, 54 percent is used for irrigation, 29 percent is used by industry, and 17 percent is used for public water supply. Ground-water withdrawal in the U.S. Virgin Islands is about $1.9 \mathrm{hm}^{3} / \mathrm{yr}$ and is almost equally distributed between public supply and privately owned wells. Based on past trends and future economic expectations in the region, estimates are that by 1985 ground-water pumpage in Puerto Rico will be about $426 \mathrm{hm}^{3} / \mathrm{yr}$ with additional future development potential; U.S. Virgin Islands pumpage may amount to $4.5 \mathrm{hm}^{3} / \mathrm{yr}$, which is the estimated maximum sustained yield of all aquifers under natural recharge conditions.

Most large ground-water developments in Puerto Rico have been in the North Coast and South Coast ground-water provinces. The North Coast province contains the island's most productive aquifer, which was virtually undeveloped until 1968, when an artesian system having a 150-meter head was tapped. Since then, the artesian aquifer has undergone rapid development for industrial water supply. The extent of the artesian system is unknown, but it has been tapped within the Montebello Limestone Member of the Cibao Formation and in the upper part of the Lares Limestone. The south-coast aquifer consists of deep alluvial deposits. This aquifer has been extensively developed for irrigation and industrial water supply and can sustain only minor future development under present water-management conditions.

In the U.S. Virgin Islands the most extensive aquifer is fragmented igneous rock, but the most productive aquifers are the marl and alluvial deposits of central St. Croix. Although yields from wells in central St. Croix are low (less than 6.3 liters per second), the aquifer provides about $0.86 \mathrm{hm}^{3} / \mathrm{yr}$ to public water-supply wells and $0.54 \mathrm{hm}^{3} / \mathrm{yr}$ to private wells. Future development within this aquifer could probably produce an additional $1.0 \mathrm{hm}^{3} / \mathrm{yr}$ under natural infiltration conditions.

Ground-water resources will continue to be important within the region. In order to meet future needs, it is necessary that hydrologic principles be applied in managing the total water resource. Optimal use of the water resources can be accomplished through conjunctive use of surface and ground waters and through conservation practices. Optimal use may involve artificial recharge, ground-water salvage, saline-ground-water mining, use of seawater, desalination of saline ground water, waste-water reuse, and use of underground space for temporary storage of wastes, which could otherwise contaminate valuable water supplies.

\section{INTRODUCTION}

To meet future water needs, it is necessary that ground-water and surface-water sources be seen as inseparably related parts of a water-supply system. This report is intended to serve as a preliminary source of information on the ground-water resources for land and water planners and managers. The analysis presented in this report includes assessments of the significance of the ground-water resource in regional water supply, quantities of ground water available, quality of the water, present and potential problems associated with its use, possible remedial measures for optimum development of the ground-water resource, and information deficiencies that restrict efficient development of this resource.

The Caribbean Region, as referred to in this report, consists of Puerto Rico and its offshore islands (Vieques, Culebra, and Mona Islands) and the U.S Virgin Islands of St. Croix, St. Thomas, and St. John.

\section{GENERAL DESCRIPTION OF THE CARIBBEAN REGION}

\section{AREAL EXTENT}

Puerto Rico and the U.S. Virgin Islands lie within lat $17^{\circ} 41^{\prime} \mathrm{N}$. and lat $18^{\circ} 31^{\prime} \mathrm{N}$. and long $64^{\circ} 40^{\prime} \mathrm{W}$. and long $67^{\circ} 57^{\prime}$ W. (fig. 1). Puerto Rico and its three offshore island have an overall area of $8,990 \mathrm{~km}^{2}$ (square kilometers); the Virgin Islands have $350 \mathrm{~km}^{2}$. Each political unit, although an integral part of the United States, has a distinct status arrangement.

\section{SOCIOPOLITICAL AND ECONOMIC SETTING}

The Caribbean Region has undergone a rapid economic and social transformation since the end of the World War II. It has changed from an agriculturally 
based economy (sugarcane, tobacco, and coffee) to one largely dependent on industrial development, its related services, and tourism. Basic statistics of the region's economic growth and population increase are given in figures $2 A$ and $2 B$.

\section{CLIMATE}

The Caribbean Region has a land surface area of 9,340 $\mathrm{km}^{2}$ and a diverse physical environment. This diversity is caused by topography and its effects on precipitation more than by any other factor. Physiographically, Puerto Rico's outlying islands-Vieques, Culebra, and Mona - can be grouped with the U.S. Virgin Islands.

Being within the influence of the trade winds, the region is exposed to a relatively persistent air flow from the east-northeast. Orographic effects are pronounced in Puerto Rico, resulting in large amounts of rainfall occurring on the windward slopes of the mountains whereas the leeward side, or south coast, lies within a rain shadow (fig.3).

The orographic effect is not as pronounced on the smaller, lower islands, and the greatest rainfall is centered on their highest peaks. On Vieques and St. Croix, for example, the low eastern ends of the islands have an annual mean precipitation of about $730 \mathrm{~mm}$ (millimeters), while on the higher west and central parts of the islands the annual means are 1,000-1,140 mm.
The major rainfall events in the Caribbean Region are caused by two mechanisms: easterly waves and cold fronts. Easterly waves generally occur from May to November, and cold fronts, from November to April.

In the Caribbean Region, rainfall normally results in seasons that are relatively rather than absolutely dry or wet (fig. 4). On all the islands the driest months are February and March. Almost every year, however, rainfall is deficient in some area for varying periods, and drought results.

One of the most extreme droughts during the recent record, of 1899 to the present, affected the Caribbean Region in the late 1920's. Another occurred in the late 1960 's. During the latter period, Puerto Rico's mean annual rainfall for 1967-1968 was $1,090 \mathrm{~mm}$, compared with a long-term mean value of $1,850 \mathrm{~mm}$. Although there is no definite pattern of dry and wet periods, a 10 -year running average at various stations (fig. 5) shows that a variation of at least $200 \mathrm{~mm}$ exists between the average rainfall of dry and that of wet periods. A similar trend was found by Jordan (1975) in St. Croix.

A significant part of the rainfall in the Caribbean area is lost to evapotranspiration. Where rainfall is about $1,000 \mathrm{~mm}$ or less, actual evapotranspiration is essentially equivalent to rainfall (fig. 6). As a result only one or two months a year may show a surplus of rainfall over potential evapotranspiration in the areas of low rainfall.

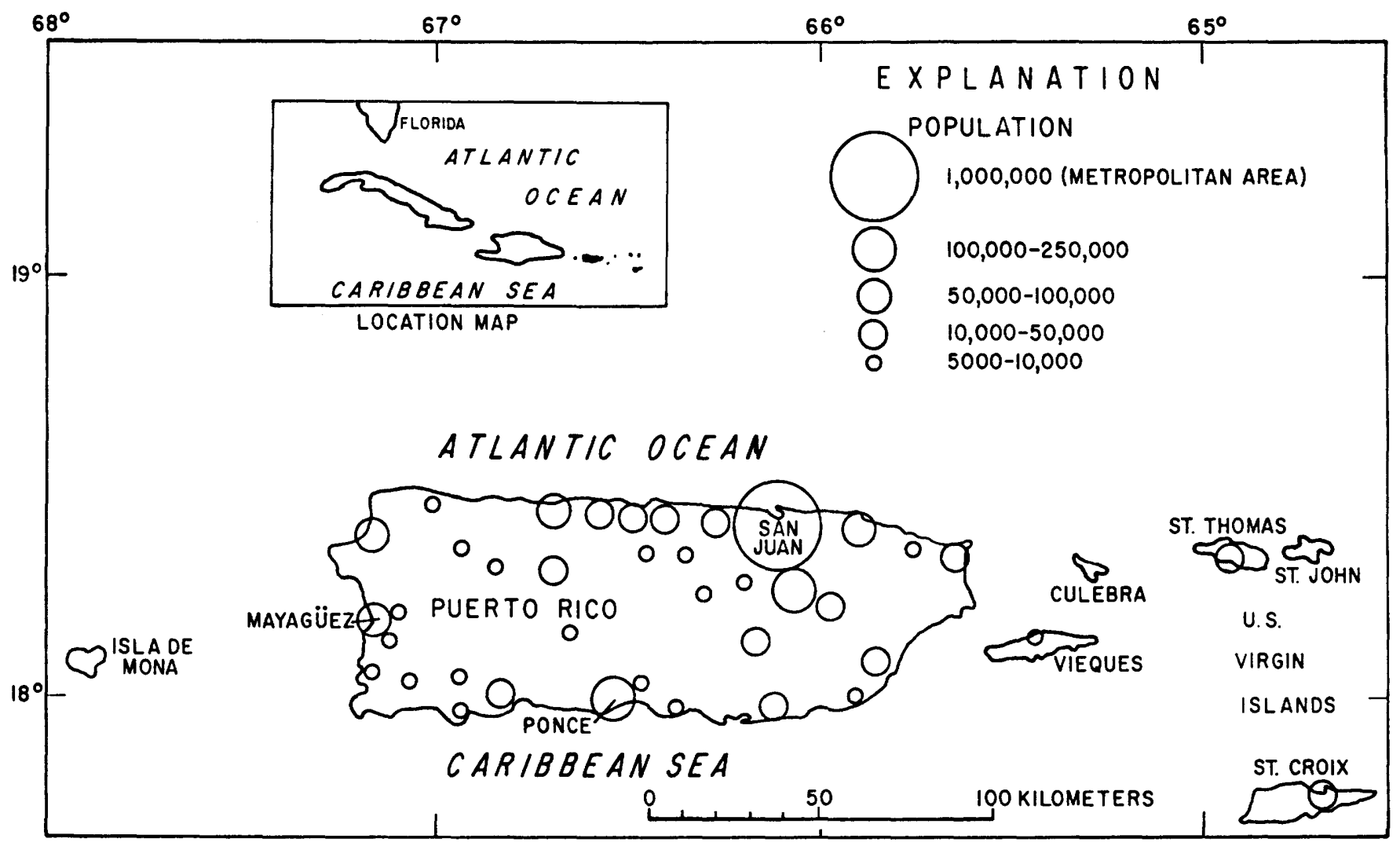

FIGURE 1.- Location, areal extent, and urban areas of the Caribbean Region. 


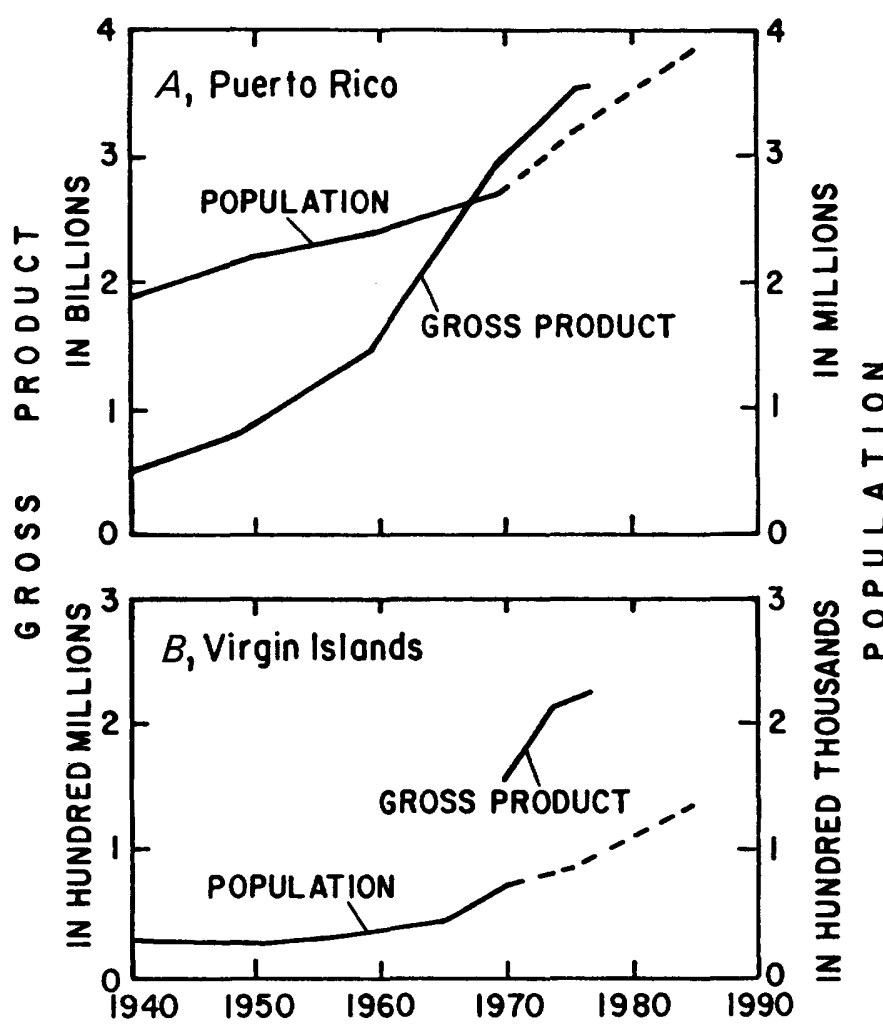

FIgURE 2.-Population trends and projections (dotted lines) and economic growth (gross product), based on the 1955 value of the U.S. dollar. $A$, For Puerto Rico. $B$, For the U.S. Virgin Islands.

\section{GEOLOGY AND HYDROGEOLOGY}

The nature of occurrence of ground water and procedures for efficient withdrawal and management of the resource are controlled in large measure by the geology.

The central core of Puerto Rico consists largely of volcanic and intrusive rocks of Late Cretaceous and early Tertiary age (fig. 7). The volcanic rocks are predominately ashy shale, agglomerate, and tuff, and most of them are thoroughly indurated. These rocks are interbedded with thick, dense lava flows and relatively thin beds of limestone, which have been partly recrystallized in many places. The volcanic rocks and interbedded limestones have been complexly faulted, folded, metamorphosed, and intruded by dioritic rocks. The massive, dense dioritic intrusions are exposed by erosion in two large areas and in many small areas on the island. Massive, dense serpentinite and associated silicified rocks, reported to be the oldest rocks in Puerto Rico (Mattson, 1960, p. 324), underlie large areas in the southwestern part of the island.

The complex central core of Puerto Rico is flanked on the north and south by clastic sediments and limestones of Oligocene and Miocene age. The older clastic sediments are composed predominately of poorly sorted mixtures of gravel, sand, and finer materials. They grade upward, however, into thick beds of relatively pure limestone. The limestones have been subjected to extensive solutional activity, which, on the north coast,

ATLANTIC OCEAN

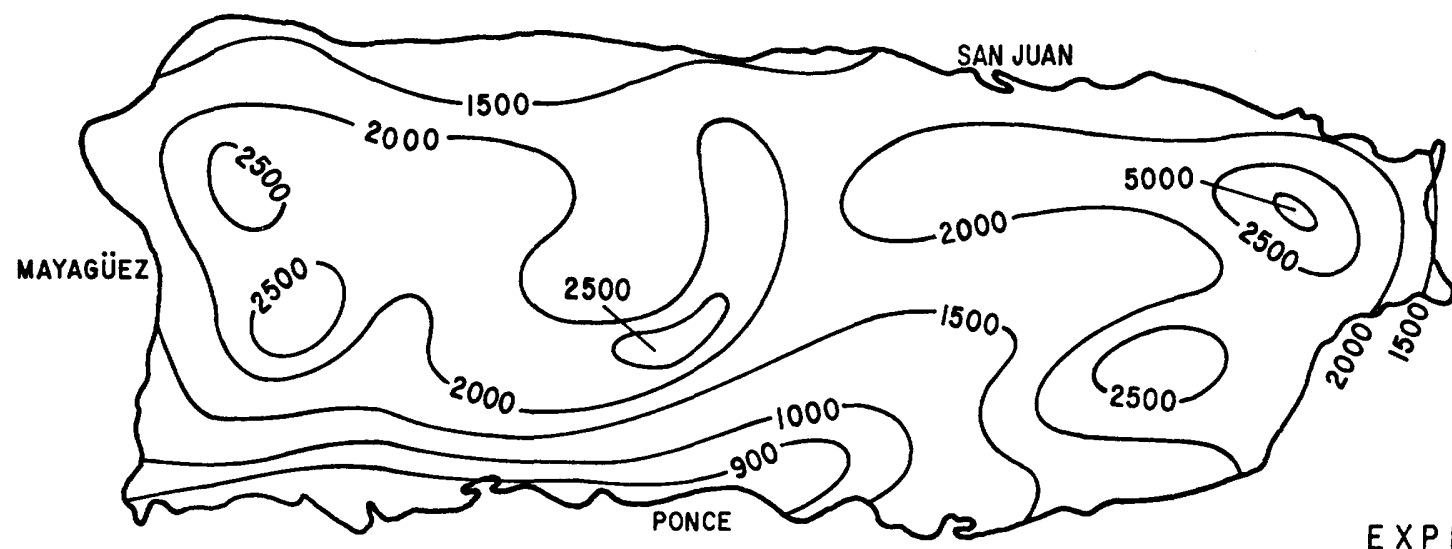

EXPLANATION

CARIBBEAN SEA

O 250 KILOMETERS

LINE OF EQUAL RAINFALL, IN MILLIMETERS

Figure 3. - Average annual precipitation, Puerto Rico. 




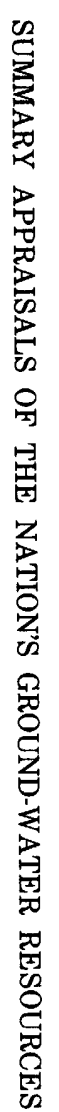

FIGURE 4. - Mean monthly long-term rainfall and annual pan evaporation in the Caribbean Region. 


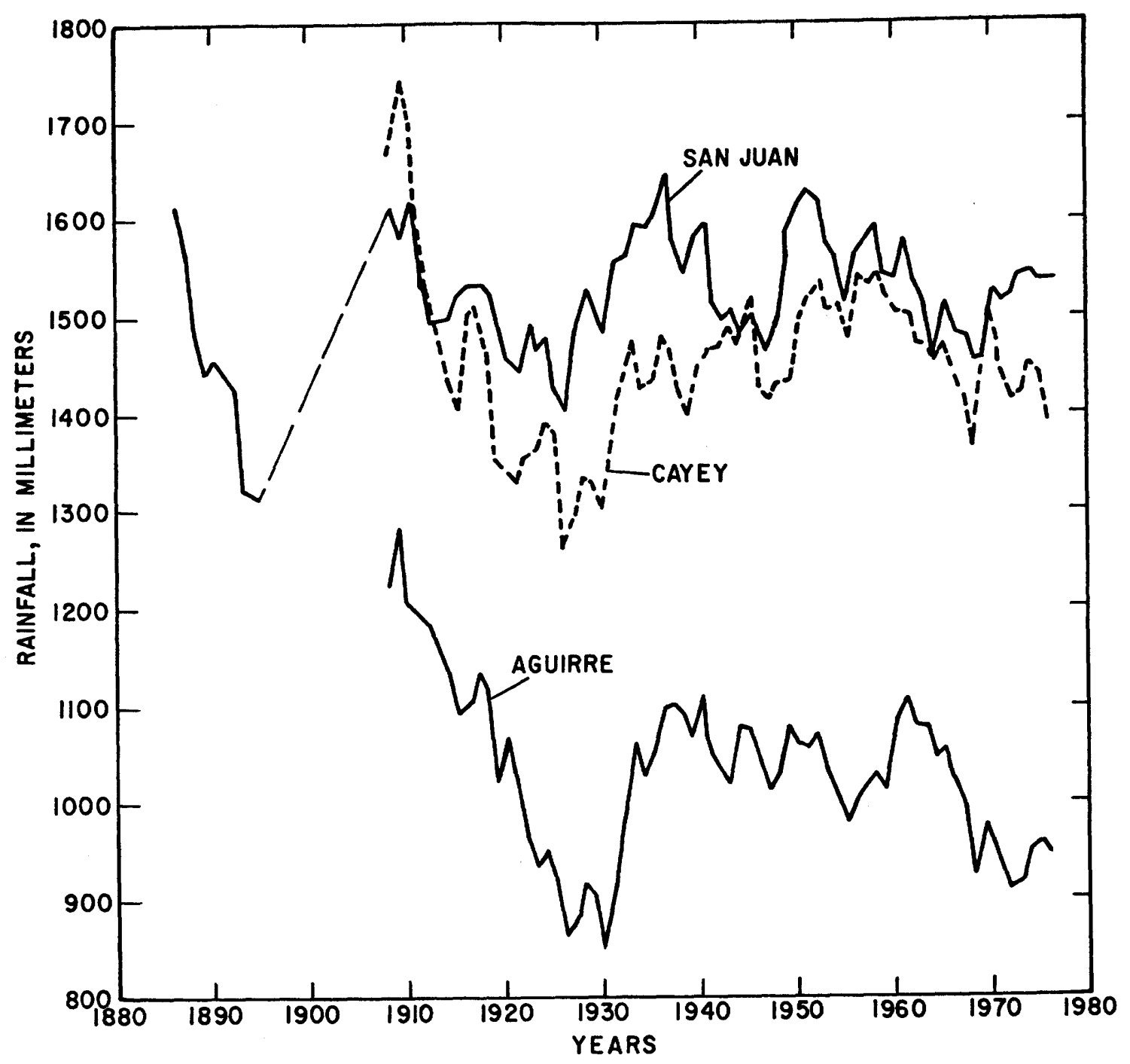

FIGURE 5. - Ten-year moving averages of rainfall at San Juan (1876-1895, 1899-1976), Cayey (1899-1976), and Aguirre (1899-1976), P.R.

has resulted in the formation of a mature karst topography.

Many of the river valleys, particularly on the north and west coasts, contain thick deposits of alluvium. In addition, an extensive blanket of alluvium along the south coast forms a plain, which averages $5.5 \mathrm{~km}$ wide and is about $65 \mathrm{~km}$ long.

The eastern half of Vieques Island is underlain by volcanic rocks of Cretaceous age, and the western half, by an extensive dioritic rock intrusion. Limestones of Miocene age fringe the south coast and the extreme eastern end of Vieques, and thin deposits of alluvium form broken plains along the north and south coasts (Meyerhoff, 1933). Culebra Island is underlain primarily by sedimentary and volcanic rocks of Cretaceous age.
Mona Island is underlain entirely by cavernous limestone and dolomite of Miocene age (Kay, 1959, $\mathrm{p}$. 141).

Some time after the deposition of the limestone during middle Tertiary time, Puerto Rico was separated from the other major Antillean Islands by block faulting and was arched, uplifted, and tilted to the northeast. Culebra, Vieques, and the Virgin Islands are part of the Puerto Rican block, and they are separated from the main island simply because of the drowning that resulted from the tilting.

The Virgin Islands of St. Thomas and St. John are underlain by indurated volcanic rock and sedimentary rock derived primarily from material eroded from the volcanic core; all these rocks are of Cretaceous age. The 




FIGURE 6. - Potential and actual evapotranspiration and their ratio as a function of rainfall (from Guisti, 1978). Dots represent pan-evaporation data; $\mathbf{x}$ 's represent actual evapotranspiration (rainfall minus runoff as obtained from watersheds where ground-water outflow is negligible and ground-water storage was assumed constant).

only nonvolcanic rock is a thin bed of limestone of Cretaceous age present on both islands. Alluvial deposits are present in the major stream valleys and interfinger with beach sand in the coastal embayments.

St. Croix also is underlain by volcanic rock and sedimentary rock derived from the erosion of older volcanic rocks, but these rocks, in turn, have been intruded by gabbro and diorite of Tertiary age. The east and west parts of the island are separated by a graben filled with altered volcanic ash that is overlain by marl and limestone. Most of the stream valleys that head in the volcanic uplands were incised during Pleistocene time, and the coastal reaches of the over-deepened valleys are filled with fine-grained alluvium.

\section{GROUND-WATER PROVINCES, PUERTO RICO}

For the purpose of this report, the island of Puerto Rico has been divided into six ground-water provinces: the North Coast, South Coast, Lajas Valley, West Coast, East Coast, and Interior (fig. 8). These divisions essentially follow that of McGuinness (1948), except that the Lajas Valley has been considered separately from the South Coast province because of its distinct physiographic and hydrologic features. The hydrologically isolated condition of Puerto Rico's offshore islands and the U.S. Virgin Islands makes it necessary to consider each island individually.

A feature common to all the ground-water provinces of Puerto Rico, Puerto Rico's offshore islands, and the U.S. Virgin Islands is the proximity of the aquifers to the sea. An interface between seawater and freshwater exists in the aquifers that is more or less in equilibrium and is maintained by the seaward flow of freshwater. A reduction in the amount of freshwater moving seaward by pumping or the lack of recharge during drought will disturb the equilibrium and cause the interface to move inland. The management of an island aquifer therefore requires that the long-term withdrawal from an aquifer does not exceed the long-term recharge or input to that aquifer. The rate at which an aquifer will yield water to wells, therefore, is not as important as the volume of water available that can be safely withdrawn from an aquifer and the recharge to that aquifer. An estimate of 
storage in the ground-water provinces of the Caribbean Region is given in table 1. A brief discussion of the hydrogeologic features of each ground-water province follows.

TABLE 1.-Ground water in storage in Puerto Rico (by province) and its offshore islands (Vieques, Culebra, and Mona Islands) and in the U.S. Virgin Islands

\begin{tabular}{|c|c|}
\hline Province or Island & $\begin{array}{c}\begin{array}{c}\text { Storage } \\
\text { (cubic } \\
\text { hectometers) }\end{array} \\
\end{array}$ \\
\hline \multicolumn{2}{|l|}{ Puerto Rico } \\
\hline \multirow{2}{*}{\multicolumn{2}{|c|}{$\begin{array}{l}\text { North Coast: } \\
\quad \text { West Coast to Río Grande de Arecibo }\end{array}$}} \\
\hline & 17,000 \\
\hline Río Grande de Arecibo to Río de La Plata & 28,000 \\
\hline & 3,200 \\
\hline South Coast & 1,500 \\
\hline Lajas Valley _- & 615 \\
\hline West Coast _....... & 400 \\
\hline East Coast & 440 \\
\hline \multicolumn{2}{|l|}{ Interior: } \\
\hline Caguas-Juncos Valley & 120 \\
\hline Cayey Valley _. & \\
\hline Other areas & 4,677 \\
\hline Subtotal & $\overline{55,955}$ \\
\hline \multicolumn{2}{|l|}{ Offshore islands: } \\
\hline Vieques _-_- & 80 \\
\hline Culebra _-_-_-_-_. & 17 \\
\hline \multicolumn{2}{|l|}{ Mona } \\
\hline Subtotal _-_- & 107 \\
\hline \multicolumn{2}{|l|}{$\begin{array}{l}\text { Total (rounded) for Puerto Rico and its offshore } \\
\text { islands }\end{array}$} \\
\hline \multicolumn{2}{|l|}{ Virgin Islands } \\
\hline St. Croix _-_-_- & 610 \\
\hline 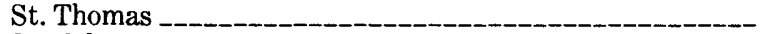 & 75 \\
\hline St. John _- & \\
\hline 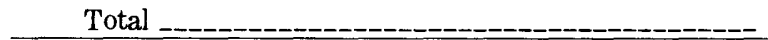 & 730 \\
\hline
\end{tabular}

\section{NORTH COAST PROVINCE}

The North Coast province covers about one-fourth of Puerto Rico and extends from the island's west coast eastward to the Río Espiritu Santo. It comprises primarily Tertiary limestones and clastic rocks lying in a band as much as $20 \mathrm{~km}$ in width. Total thickness of these rocks can exceed $1,600 \mathrm{~m}$ (meters) at the coast line. Overlying much of the coastal area are blanket sands and alluvium. The blanket sands, forming flat areas between limestone hills, are as much as $25 \mathrm{~m}$ thick. Alluvium is confined chiefly to the valleys of the major rivers but forms a rather continuous blanket from metropolitan San Juan eastward. It is as much as $60 \mathrm{~m}$ thick in the major river valleys. Inland of the blanket sands and alluvium covered areas are large exposures of limestone, where extensive sinkhole formation has produced a classic tropical karst.

Four limestones constitute the principal water-table aquifer: from oldest to youngest, the Lares Limestone, the Cibao Formation, the Aguada Limestone, and the Aymamon Limestone. The hydraulic conductivity of these limestones decreases from a maximum in the up- per part of the Aymamon Limestone to a minimum in the basal Lares Limestone. Hydraulic conductivity also varies areally and is related primarily to the degree of secondary porosity due to solutioning in the limestone (table 2). The alluvium in the river valleys is in hydraulic connection with the limestones. The water-table gradient is nearly flat $(1 \mathrm{~m} / \mathrm{km})$ in the Aymamon and upper part of the Aguada, increases through the lower part of the Aguada and upper part of the Cibao $(3 \mathrm{~m} / \mathrm{km})$, and decreases again in the lower part of the Cibao and the Lares $(1 \mathrm{~m} / \mathrm{km})$.

Wells drilled in the water-table aquifer can be expected to produce $60 \mathrm{~L} / \mathrm{s}$ (liters per second) from the upper part of the Aymamon Limestone, 5-50 L/s from the lower part of the Aymamon and the Aguada Limestones, and 5-10 L/s in the Cibao Formation and Lares Limestone.

Wells tapping the alluvium in the valleys of Río Grande de Arecibo and Río Grande de Manatí will produce as much as $60 \mathrm{~L} / \mathrm{s}$. Alluvium is finer grained in the more eastern river valleys and will yield from 5 to $20 \mathrm{~L} / \mathrm{s}$ to wells. Alluvium in the San Juan metropolitan area will yield from 5 to $15 \mathrm{~L} / \mathrm{s}$ to wells.

Artesian aquifers have been found in the Montebello Limestone Member of the Cibao Formation and the upper part of the Lares Limestone in the area between Arecibo and Laguna Tortuguero. Wells tapping the Montebello Limestone Member at about lat $18^{\circ} 26^{\prime} \mathrm{N}$. will produce as much as $120 \mathrm{~L} / \mathrm{s}$. The Lares Limestone will yield less - approximately $0.2 \mathrm{~L} / \mathrm{s}$ for each meter of penetration into the aquifers. The hydraulic conductivity of these aquifers is low (table 2), and the high yields obtained when the aquifers were first tapped (1968) was due to their high head (approximately $120 \mathrm{~m}$ above sea level). The aquifers, as of 1978 , have undergone a significant loss in head (fig. 9).

Discharge from the water-table aquifer is to the rivers or to the sea and wetlands adjacent to the sea. There are a few coastal and subaqueous springs along the coast, but most discharge is apparently by general seepage to the sea. In the vicinity of Laguna Tortuguero and Caño Tiburones (pl. 2), ground-water discharge is by springs and seeps to these bodies and then by canal to the sea.

Probably all the water from the artesian aquifers discharges offshore, either at the outcropping of the aquifer or by upward leakage through confining beds. Because of the low hydraulic conductivity of the artesian aquifers, the discharge from them is a very small part of the water budget.

\section{SOUTH COAST PROVINCE}

The South Coast province consists of an alluvial plain averaging about $5 \mathrm{~km}$ in width from Patillas to Ponce 


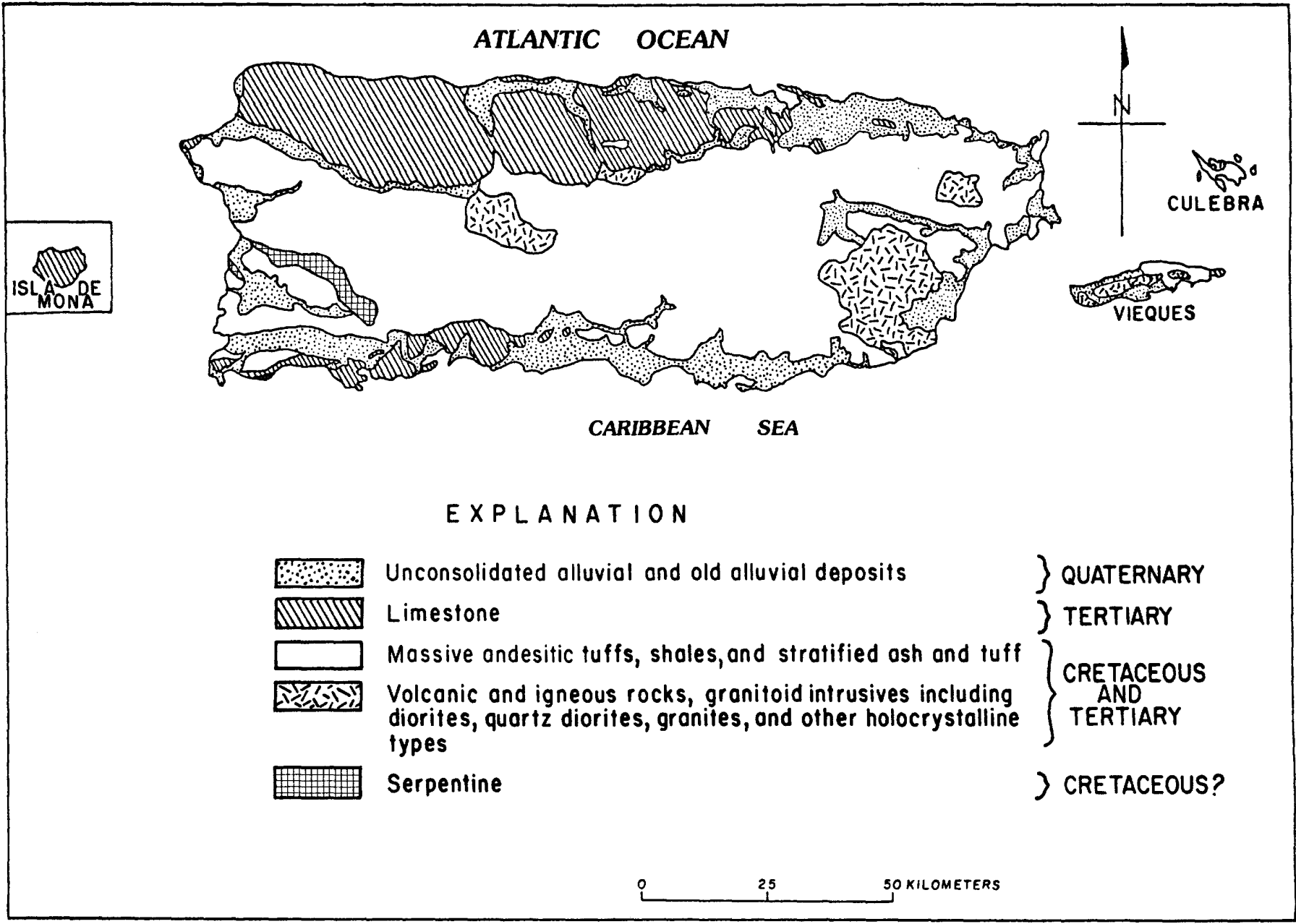

Figure 7. - Map showing general geology of Puerto Rico and its offshore islands (modified from Meyerhoff, 1933).

TABLE 2. -Ground-water flow of part of the North Coast limestones (modified from Giusti, 1976)

[Values in parentheses are estimates]

\begin{tabular}{|c|c|c|c|c|}
\hline Formation & $\begin{array}{c}\text { Thickness } \\
(\mathrm{m})\end{array}$ & $\begin{array}{c}\text { Slope } \\
(\mathrm{m} / \mathrm{km})\end{array}$ & $\begin{array}{c}\begin{array}{c}\text { Hydraulic } \\
\text { conductivity } \\
\text { (em/s) }\end{array} \\
\end{array}$ & $\begin{array}{c}\text { Discharge } \\
\left(\mathrm{m}^{3 / s)} \text { per }\right. \\
\text { kilometer width }\end{array}$ \\
\hline $\begin{array}{l}\text { Aymamon Limestone } \\
\text { Aguada Limestone } \\
\text { Cibao Limestone } \\
\text { Lares Limestone } \\
\text { Total }\end{array}$ & $\begin{array}{l}60 \\
90 \\
170-200 \\
300 \\
\end{array}$ & $\begin{array}{l}(1.0) \\
(1.0) \\
(1.0-3.0) \\
(3.0) \\
\end{array}$ & $\begin{array}{l}0.02-0.05 \\
.0020 \\
(.0005) \\
.0002 \\
\end{array}$ & $\begin{array}{l}0.0120-0.0300 \\
.0018 \\
.0010-.0051 \\
.0018 \\
.88 \text { (for } 39 \mathrm{~km} \text { ) }\end{array}$ \\
\hline \multicolumn{5}{|c|}{ Rio Grande de Arecibo to Río de La Plata area } \\
\hline
\end{tabular}




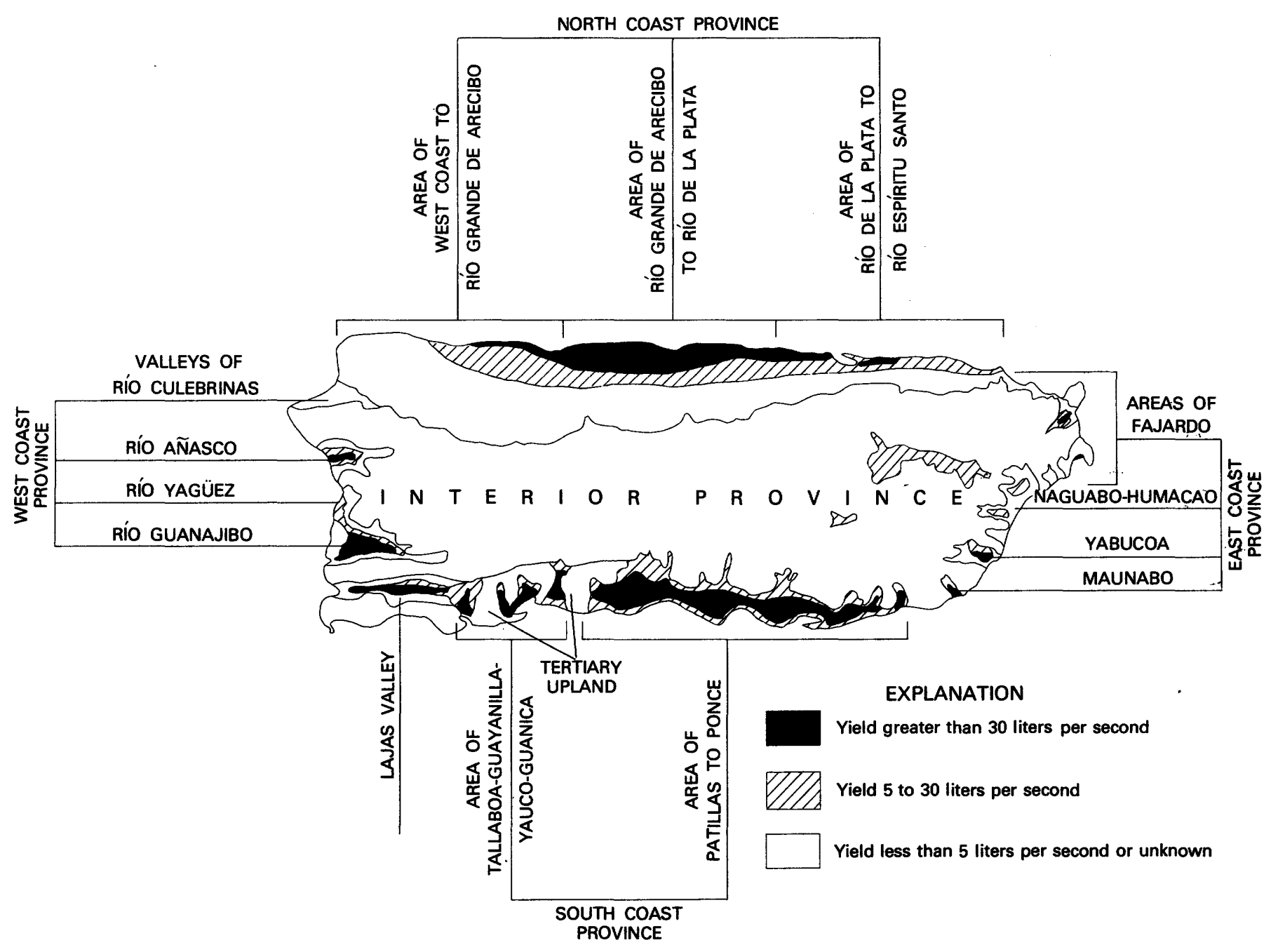

Figure 8. - Ground-water provinces and their yield to wells in Puerto Rico.

and of alluviated valleys-Tallaboa, Guayanilla, Yauco, and Gúanica (fig. 8) - cut into Tertiary limestone.

\section{PATILLAS TO PONCE AREA}

From Patillas to Ponce the alluvial plain is formed by coalescing alluvial fans (fig. 10) that have filled deepened valleys cut into bedrock of volcanic or volcanic sedimentary origin. The alluvium generally is $30-45 \mathrm{~m}$ thick near the shore line between Río Patillas and Rio Cayures but can be greater than $60 \mathrm{~m}$ in the overdeepened valleys. West of Rio Cayures to Ponce, the alluvium ranges from 60 to $90 \mathrm{~m}$ in thickness at the shoreline and commonly overlies the Ponce Limestone. As much as $610 \mathrm{~m}$ of alluvium has been penetrated along the coast between Río Cayures and Rio Jacaguas. The excessive thickness of alluvium is probably due to faulting. In the vicinity of Ponce the limestone is in hydraulic connection with the overlying alluvium.
The alluvium becomes finer grained toward the coast and in the interfluvial areas. Wells tapping the alluvium along the coast will flow intermittently. This flow is the result of the anisotropy of the water-table aquifer which is about 1,000:1 (lateral to vertical hydraulic conductivity). It is not an indication of true artesian conditions.

The alluvium will yield from 10 to $200 \mathrm{~L} / \mathrm{s}$ to wells. The largest yields are within the central areas of the alluvial fans. The Ponce Limestone will yield as much as $60 \mathrm{~L} / \mathrm{s}$ to wells in the Ponce area, but such wells are used only where production from the alluvium is low, because the water quality is not as good as that from the alluvium.

\section{TALLABOA-GUAYANILLA-Y'AUCO-GUANICA AREA}

These valleys, though small, are locally important as a water supply for sugarcane cultivation on approximately 4,500 ha (hectares) and for the petrochemical complex in the Tallaboa-Guayanilla Valleys. 


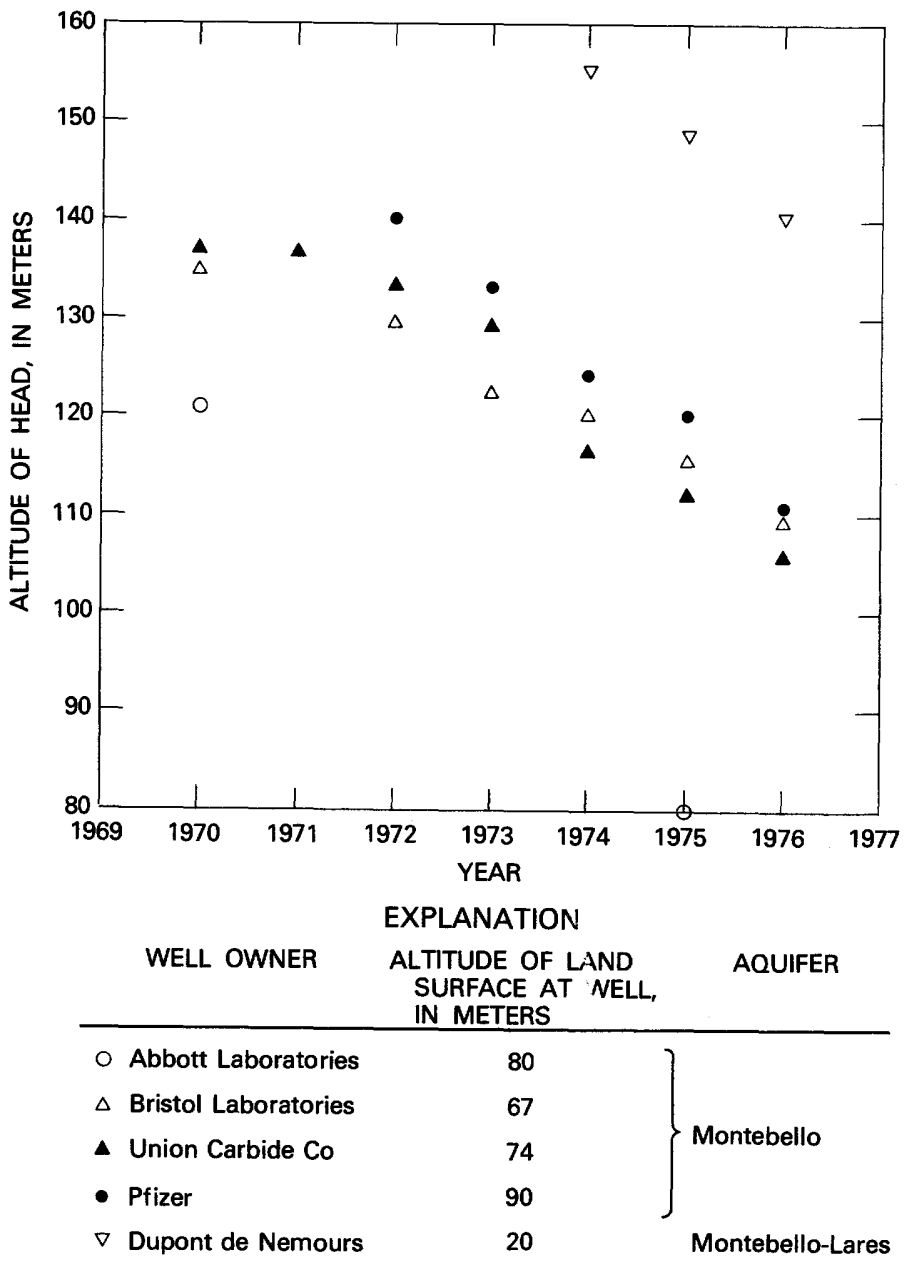

FIGURE 9. - Head of selected wells tapping the artesian aquifers of the North Coast province (modified from Morris, 1976).
The four valleys have very similar basins. Alluvium may be as much as $60 \mathrm{~m}$ thick near the coast. Fineness of materials increases seaward. Sand and gravel are more abundant in the upper part of the valleys, but the alluvium is thin. Underlying the alluvium is the Ponce Limestone, which also makes up the ridges bordering the valleys. The limestone may be as much as $1,200 \mathrm{~m}$ thick near the coast in the Tallaboa-Guayanilla-Yauco Valleys (Zapp and others, 1948) but thins to $50 \mathrm{~m}$ at Guanica. Moderate amounts of water can be obtained from the limestone along the valley walls and beneath the alluvium, where secondary porosity due to solutioning is greatest.

Yields to wells tapping the alluvium range from 0.1 $\mathrm{L} / \mathrm{s}$ to $190 \mathrm{~L} / \mathrm{s}$. The best production is at Guanica, where most irrigation wells produce more than $38 \mathrm{~L} / \mathrm{s}$. In Tallaboa Valley, wells tapping the Ponce Limestone below thick alluvial deposits produce as much as $160 \mathrm{~L} / \mathrm{s}$.

\section{LAJAS VALLEY}

The Lajas Valley in southwestern Puerto Rico trends east and west and is bound by ridges to the north and south. The valley floor, covered by alluvium, is approximately $106 \mathrm{~km}^{2}$ in area.

The alluvium filling the valley to depths reportedly in excess of $90 \mathrm{~m}$ is fine grained, predominately silt and clay. There are some sand and gravel beds in small alluvial fans formed where streams enter the valley from the north. The alluvium as a whole is a poor aquifer. A limestone aquifer underlies the alluvium in the western part of the valley, and a volcanic conglomerate and massive limestone probably compose the aquifer beneath the eastern part of the valley.

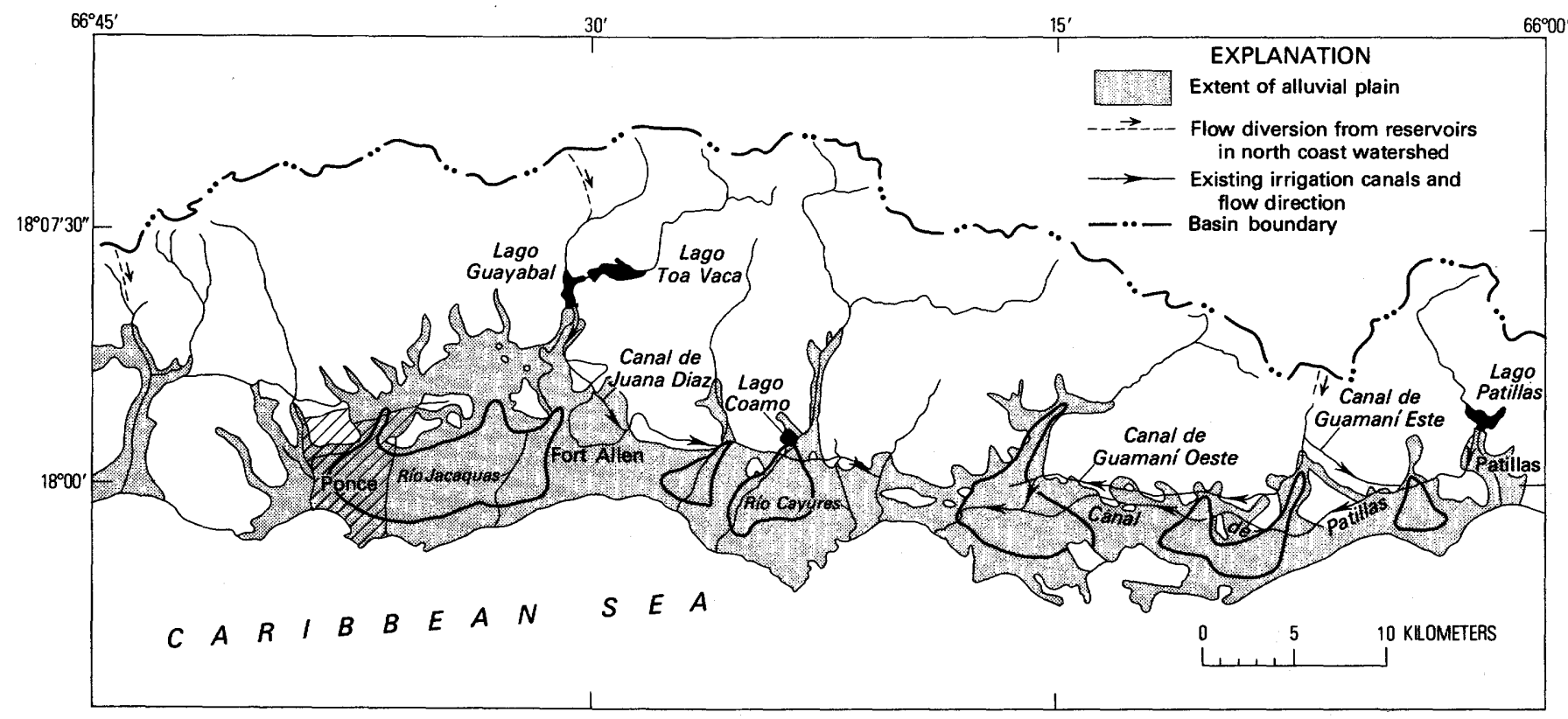

Figure 10.-Major alluvial fans of the South Coast province. 
The alluvial aquifer generally will yield but a few liters per second to wells, with the exception of the alluvial fans on the north edge of the valley, which will yield as much as $20 \mathrm{~L} / \mathrm{s}$. The limestone aquifer reportedly yielded $30-120 \mathrm{~L} / \mathrm{s}$ to wells in the 1940 's. Yield to wells of $10-30$ $\mathrm{L} / \mathrm{s}$ are obtained from what is probably the volcanic conglomerate and massive limestone aquifer.

Agriculture is the main activity in the valley and is largely dependent for irrigation on intrabasin transfer of water from Lago Loco in the Guanica Valley. Ground water was used for irrigation prior to the completion of the irrigation canals in 1955, but most irrigation wells in the valley have since been abandoned because of the poor quality of the ground water. Presently the only wells used for irrigation are in the La Plata Basin. There are a number of small-capacity wells used for stock watering. The major ground-water discharge is by flowing relief wells and tile underdrains used to control water-logging of soils in the eastern part of the basin. The decline in ground-water pumpage and the importation of surface water apparently has had an impact on the water budget of the valley. Water budget estimates indicate that net recharge is approximately $5.5 \mathrm{hm}^{3} / \mathrm{yr}$ (cubic hectometers per year). By means of a salt-balance calculation, Anderson (1977) estimated the recharge to be about $45 \mathrm{~mm} / \mathrm{yr}\left(5 \mathrm{hm}^{3} / \mathrm{yr}\right)$. This "net input" may be real, for 74 percent of the valley had water-table increases in 1974; this trend has been observed since introduction of irrigation water from Lago Loco reservoir in 1955.

\section{WEST COAST PROVINCE}

Four alluvial valleys on the west coast have some potential for ground-water development (fig. 8). The greatest potential exists in the Río Guanajibo valley (89 $\mathrm{km}^{2}$ ), but moderate amounts of freshwater can be obtained from the Río Yaguez valley $\left(7 \mathrm{~km}^{2}\right)$, the Río Grande de Añasco valley $\left(48 \mathrm{~km}^{2}\right)$, and the Río Culebrinas valley $\left(41 \mathrm{~km}^{2}\right)$. Sugarcane cultivation and processing are the main activities in the Guanajibo, Añasco, and Culebrinas areas. In the Río Yaguez valley, the town of Mayagüez and adjacent urban development have almost completely covered the alluvial surface.

The Rio Guanajibo valley deposits consist of detrital clay, silt, sand, and gravel and one or more beds of limestone. Depth of alluvium is at least $24 \mathrm{~m}$. Limestone in the western part of the valley is more than $30 \mathrm{~m}$ thick but thins to the east and is reported to be absent near San Germán (Anders, 1968).

Yields of the more productive wells tapping both alluvium and limestone in Río Guanajibo valley range from $25 \mathrm{~L} / \mathrm{s}$ to $95 \mathrm{~L} / \mathrm{s}$. Wells tapping alluvium are more numerous and have yields between 1.5 and $38 \mathrm{~L} / \mathrm{s}$.
In the Río Yaguez valley, alluvium is the principal aquifer and has a maximum known thickness of $60 \mathrm{~m}$ (Bogart and others, 1964). The alluvial deposits are underlain by alternating layers of clastic sediments and limestone. Well yields are reported between 3 and 25 $\mathrm{L} / \mathrm{s}$. Yields of more than $25 \mathrm{~L} / \mathrm{s}$ may be possible for wells in alluvium near the Río Yaguez or where fragmented limestone is overlain by alluvium.

The Río Grande de Añasco alluvial valley is relatively flat and has poor drainage. Alluvium is as much as $139 \mathrm{~m}$ thick, the maximum reported depth. The alluvium consists predominately of clay strata interbedded with beds of sand and limestone. The better water-yielding areas may be located toward the center of the valley and possibly in the apex of the alluvial fan, where more sand and gravel are likely to have been deposited.

No information is currently available on the alluvial aquifer of the Río Culebrinas valley, but the aquifer is probably similar to that of the Río Grande de Añasco.

\section{EAST COAST PROVINCE}

This province consists of the coastal area extending east of Punta Picua on the northeast to the Río Maunabo valley on the southeast. Four major areas make up this province: Fajardo, Naguabo-Humacao, Yabucoa, and Maunabo.

FAJARDO AREA

This area consists of the interrupted narrow coastal plain and small valleys from Punta Pićua on the north to Punta Lima on the east coast. Alluvium, the principal aquifer, consists of lenticular beds of clay, sand and gravel, and rock fragments to a depth less than $30 \mathrm{~m}$. The best water yielding formations are in the vicinity of Fajardo. Yields to wells range from 13 to $62 \mathrm{~L} / \mathrm{s}$, but the water is brackish to salty. Most attempts at obtaining freshwater have failed in this area. Fresh ground-water yields as much as $60 \mathrm{~L} / \mathrm{s}$ may be possible in the upper alluvial valley of the Río Fajardo, where inflow may be induced from the river through the predominating gravel and sand deposits.

\section{NAGUABO-HUMACAO AREA}

This area includes the coalescing alluvial deposits in the lower valleys of the Ríos Santiago, Blanco, Anton Ruíz, Humacao, and Candelero. Alluvium in most of the area consists of clay and silt. Alluvium in the Río Humacao, which is derived from the granitic San Lorenzo batholith, has considerable quantities of sand. The maximum recorded thickness of alluvium is $50 \mathrm{~m}$ in the valley of the Río Anton Ruíz. Yields to large diameter 
wells obtaining water from fine-grained alluvium average about $9.5 \mathrm{~L} / \mathrm{s}$, whereas wells tapping sand and gravel beds such as found in the upper valley of the Río Anton Ruiz yield as much as $32 \mathrm{~L} / \mathrm{s}$.

\section{YABUCOA AREA}

This area consists of the Yabucoa Valley, which has been incised in the San Lorenzo batholith. Alluvium is as much as $122 \mathrm{~m}$ thick in a depression near the center of the valley and about $30 \mathrm{~m}$ at the artificial harbor at the southeast edge of the valley. The alluvium consists largely of clay but has appreciable amounts of sand. Yields to wells average about $32 \mathrm{~L} / \mathrm{s}$ and range between $6 \mathrm{~L} / \mathrm{s}$ and $127 \mathrm{~L} / \mathrm{s}$.

Optimum development of the aquifer under present conditions would yield $45,000 \mathrm{~m}^{3} / \mathrm{d}$ (cubic meters per day) (Robison and Anders, 1973).

\section{MAUṆABO AREA}

The main aquifer in the Maunabo area is alluvium as much as $60 \mathrm{~m}$ thick that contains lenticular deposits of sand, gravel, and cobbles.

Well yields in the alluvial valley range from $1 \mathrm{~L} / \mathrm{s}$ to 95 $\mathrm{L} / \mathrm{s}$. Yields greater than $30 \mathrm{~L} / \mathrm{s}$ may be possible to wells constructed in places where sand and gravel are well sorted and have a saturated depth in excess of $30 \mathrm{~m}$. Wells along the Rio Maunabo and Quebrada Arenas have high yields because of induced infiltration from the streams.

Optimum development of the aquifer under present conditions would yield about $8,000 \mathrm{~m}^{3} / \mathrm{d}$, as indicated by a model analysis (Adolphson and others, 1977).

\section{INTERIOR PROVINCE}

Most of the Interior province is mountainous terrane consisting of volcanic rocks, a few interbedded limestones, and intrusive rocks. Small isolated alluvial deposits are present in the major river valleys. In the Caguas-Juncos Valley $\left(80 \mathrm{~km}^{2}\right)$, alluvium consisting of clay, sand, and gravel averages about $18 \mathrm{~m}$ thick in the vicinity of Caguas and about $37 \mathrm{~m}$ at Gurabo. In the Cayey Valley $\left(8.7 \mathrm{~km}^{2}\right)$, alluvium consists predominately of clay and rock fragments and averages about $7.5 \mathrm{~m}$ in thickness.

The bedrock will yield from 1 to $30 \mathrm{~L} / \mathrm{s}$ to wells that tap fracture systems. The higher yields usually are obtained in the valleys where fractures are more abundant. Yields to wells from the alluvium and underlying bedrock in the Caguas-Juncos Valley average about 15 $\mathrm{L} / \mathrm{s}$ and in the Cayey Valley, about $11 \mathrm{~L} / \mathrm{s}$.

\section{WATER QUALITY}

A seawater-freshwater interface is present in the aquifers throughout the coastal areas of Puerto Rico, usually within a short distance inland of the coastline. The greatest inland penetration is adjacent to rivers and lagoons or where ground-water pumpage has caused encroachment. Water from alluvial aquifers along the coast locally will have high concentrations of iron and manganese. The source of these minerals is unknown, but they may be derived from buried swamp or lagoon deposits.

In southwest Puerto Rico a magnesium bicarbonate water, high in silica, is present in serpentine rock and in adjacent aquifers that receive drainage from the rocks. Water in the Lajas Valley is a sodium bicarbonatesodium chloride type; the minerals are probably the result of residual seawater trapped in the aquifers and of concentrations from bulk precipitation.

Ground water throughout most of Puerto Rico is of a calcium bicarbonate type (fig. 11), differing mainly in the concentration of dissolved solids (table 3).

TABLE 3. - Range in dissolved-solids concentration for ground water in Puerto Rico

\begin{tabular}{|c|c|c|}
\hline Province & Aquifer & $\begin{array}{c}\text { Range of } \\
\text { dissolved } \\
\text { solids (mg/L) }\end{array}$ \\
\hline North Coast ___ & $\begin{array}{l}\text { Water table: limestone and } \\
\text { alluvium. }\end{array}$ & $200-500$ \\
\hline Do & $\begin{array}{l}\text { Artesian: limestone and } \\
\text { clastic rocks. }\end{array}$ & $300-400$ \\
\hline South Coast & Alluvium _-_-_-_-_-_- & $300-500$ \\
\hline Do & Limestone & $500-800$ \\
\hline Lajas Valley & $\begin{array}{l}\text { Alluvium, limestone, and } \\
\text { conglomerate. }\end{array}$ & $1,000-4,000$ \\
\hline West Coast & Alluvium and limestone & $300-500$ \\
\hline East Coast & - & $100-300$ \\
\hline Interior & Volcanic rocks ___ & $200-500$ \\
\hline Do & Intrusive rocks & $100-200$ \\
\hline------- & Serpentine -- & $500-800$ \\
\hline
\end{tabular}

\section{PUERTO RICO'S OFFSHORE ISLANDS}

\section{VIEQUES}

The $132 \mathrm{~km}^{2}$ of Vieques is underlain by volcanic rock and granodiorite (fig. 7). Small patches of limestone are present on the north and south coasts and the eastern tip of the island. The principal aquifers are the sandy alluvial deposits in the major valleys. Only two of the alluvial deposits are significant to the water-supply of the island-those in the Resolucion Valley on the west end of the island and those in the vicinity of Esperanza on the southwest coast.

The alluvial deposits will yield from 0.5 to $2 \mathrm{~L} / \mathrm{s}$ to wells, whereas the fractured bedrock will commonly yield less than $0.5 \mathrm{~L} / \mathrm{s}$, as does the limestone of the south coast.

The civilian population, between 9,000 and 10,000 inhabitants, relies almost entirely on ground-water pro- 


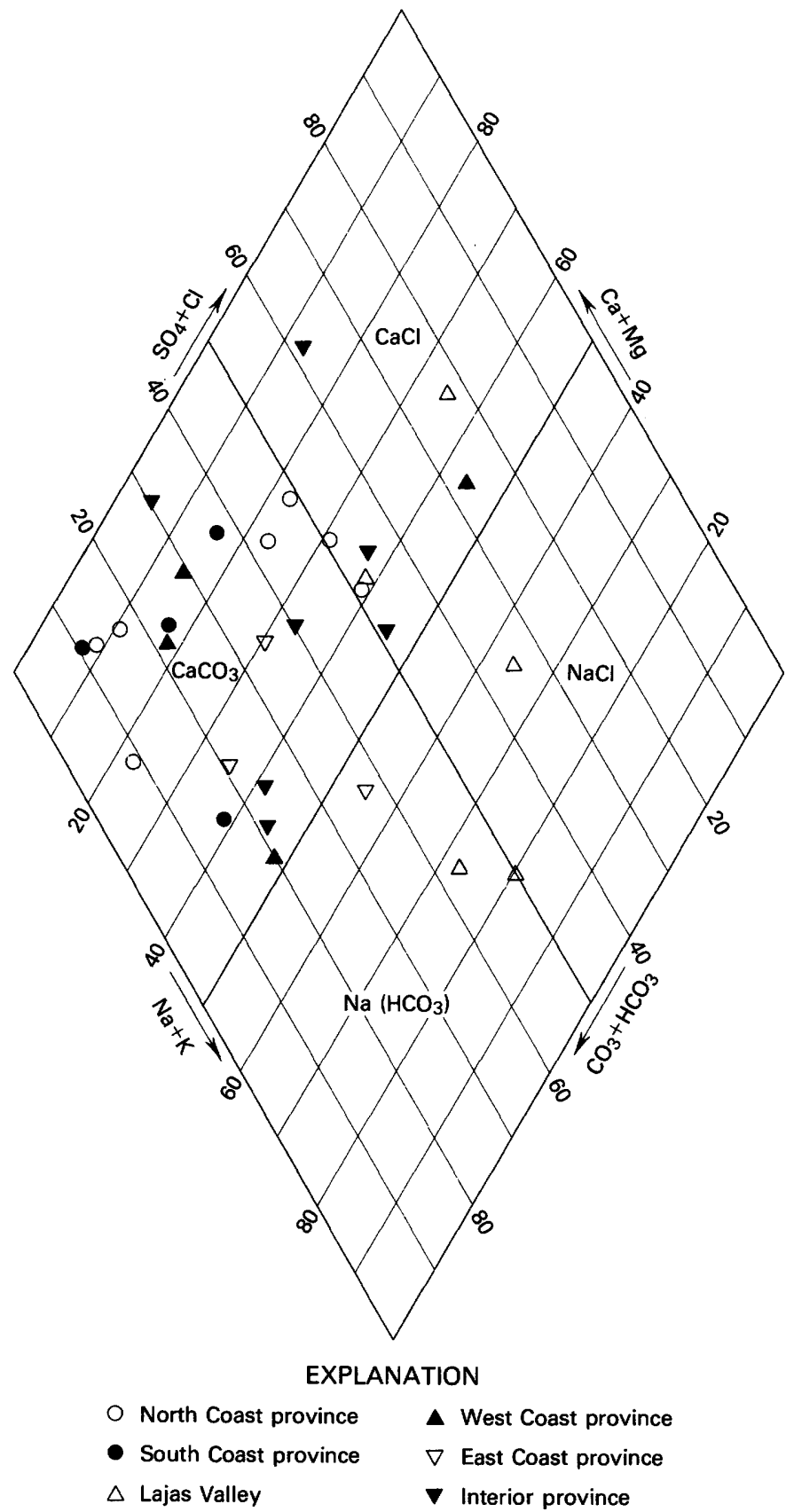

FIgURE 11. - Water-classification diagram for ground water of Puerto Rico.

duction at Esperanza, which averages about $1,500 \mathrm{~m}^{3} / \mathrm{d}$. It is expected that by 1978 , water will be made available to the island by pipeline from Puerto Rico.

Ground water in Vieques is a sodium bicarbonatesodium chloride type, unfit for irrigation because of the sodium hazard to soils. Wells drilled in bedrock in the higher elevations have the best quality water, having chloride concentrations of about $70 \mathrm{mg} / \mathrm{L}$ (milligrams per liter). Within the thin alluvium deposits at Esperanza and Colonia Luján, best quality waters have chloride concentrations of about $90 \mathrm{mg} / \mathrm{L}$ and total dissolved solids of about $700 \mathrm{mg} / \mathrm{L}$. Water from wells within the area also contain nitrate concentrations as' high as 44 $\mathrm{mg} / \mathrm{L}$, probably derived from the manure of the large number of cattle on the island.

\section{CULEBRA}

The island of Culebra consists principally of volcanic rock (fig. 7) overlain by a thin soil cover seldom more than $0.3-0.6 \mathrm{~m}$ thick over much of the island. Thicker coluvial deposits exist on a high plain having drainage to Ensenada Honda. Approximately $400 \mathrm{~m}^{3} / \mathrm{d}$ of water may be available from wells drilled in fractured volcanic rock within the valleys having drainage to Ensenada Honda (Jordan and Gilbert, 1976). Of this amount, about 110 $\mathrm{m}^{3} / \mathrm{d}$ has been developed at the Puerto Rico Aqueducts and Sewers Authority (PRASA) well field on the high plain. The well field, which consists of four wells, each having a yield of about $1 \mathrm{~L} / \mathrm{s}$, supplements the public water supply for the community of Culebra when a desalination plant does not meet the demand. The desalination plant consists of two vapor compression units, each rated at $0.66 \mathrm{~L} / \mathrm{s}$.

Most of the potential ground-water resource is of marginal quality for domestic use. Dissolved solids commonly exceed $1,000 \mathrm{mg} / \mathrm{L}$, and chloride concentration is about $450 \mathrm{mg} / \mathrm{L}$. The mineral content of the ground water is due principally to the concentration of minerals from bulk precipitation and sea spray and does not result from geologic factors or saltwater intrusion.

\section{MONA}

Mona is an uninhabited enormous white slab of limestone and dolomite bounded almost entirely by cliffs rising vertically from the water to a maximum altitude of $60 \mathrm{~m}$. Ground water is produced only from several shallow dug wells located in a coastal plain about $1 \mathrm{~km}$ wide on the southwest edge of the island. This coastal plain rises to about $5 \mathrm{~m}$ above sea level and is composed of sand and reef deposits.

No springs have been reported emerging from the cliffs, even during major rainstorms. This may indicate that the limestone has a high permeability and is capable of conveying a large percentage of rainfall to the water table. Jordan (1973) estimated that under such conditions the water table beneath Mona resembles a lens, with the apex near the island's center. This condition could exist if a north-south trending fault has an insignificant effect on hydraulic characteristics.

The most favorable location for ground-water development would be at the edge of the cliffs on the coastal plain. If the freshwater lens is not sufficiently thick at 
this site to sustain development, the other possibility would be drilling near the island's center.

Bulk precipitation and salt spray should be a significant source of dissolved solids in the ground water. Even in the center of the freshwater lens, ground water likely will have dissolved solids in excess of $1,000 \mathrm{mg} / \mathrm{L}$ and a chloride concentration of about $200 \mathrm{mg} / \mathrm{L}$. A shallow dug well on the coastal plain (Pozo del Portugués) had dissolved solids of about $3,000 \mathrm{mg} / \mathrm{L}$ and a chloride concentration of $980 \mathrm{mg} / \mathrm{L}$ (1977).

\section{U.S. VIRGIN ISLANDS}

\section{ST. CROIX}

The three water-bearing units in St. Croix correspond in lithology to the general geology of the island, which is composed of volcanic and associated sedimentary and intrusive rocks, marl and limestone, and alluvium (fig. 12).

The principal water-bearing zones in the intrusive, volcanic, and associated rocks are interconnected open fractures and joints at depths of less than $100 \mathrm{~m}$. These fracture and joint systems commonly yield $0.3 \mathrm{~L} / \mathrm{s}$ or less to wells, although occasionally yields as large as 2 $\mathrm{L} / \mathrm{s}$ can be obtained.

The marl and limestone compose the most productive aquifer. Major water-bearing zones are calcareous sandstone along the south coast, which will yield as much as 5 $\mathrm{L} / \mathrm{s}$ to wells. The interior of central St. Croix is underlain primarily by marl, which yields little water to wells. Elsewhere yields of 1-2 L/s are possible.

Alluvial deposits generally are but a few meters in thickness, except where they fill overdeepened bedrock valleys. Alluvium in the River Gut Basin will yield between 0.5 and $3 . \mathrm{L} / \mathrm{s}$ to wells, depending upon the thickness of sand and gravel beds encountered. Elsewhere on the island the alluvium is generally fine grained and will yield little water to wells. The alluvium is important, however, as it is readily infiltrated by rain and streamflow and acts as a temporary reservoir for recharge to the underlying rocks.

Ground-water quality in St. Croix is greatly affected by bulk precipitation and geology. The water is basically a calcium bicarbonate-sodium chloride type. Chloride concentrations in good productive wells $(0.6 \mathrm{~L} / \mathrm{s}$ or more) are rarely less than $200 \mathrm{mg} / \mathrm{L}$. In general, little of the water in St. Croix meets quality recommendations for drinking water as far as dissolved solids and chloride concentration are concerned (National Academy of Sciences, National Academy of Engineering, 1974), but locally the water is considered potable if chlorides are less than $500 \mathrm{mg} / \mathrm{L}$. The best water is that from the volcanic rock, where dissolved solids range between 500 and $1,000 \mathrm{mg} / \mathrm{L}$. Total dissolved-solids concentration, in water from the better producing wells tapping limestone and marl, range from 1,500 to $3,000 \mathrm{mg} / \mathrm{L}$ but are as high as $20,000 \mathrm{mg} / \mathrm{L}$ in the headwaters of Salt River. Such high concentrations may be from connate seawater entrapped in the Middle Tertiary Kingshill Marl and underlying Jealousy Formation during deposition.

\section{ST. THOMAS AND ST. JOHN}

Volcanic rocks and sedimentary rocks derived from the volcanic rocks constitute the principal aquifer on St. Thomas and St. John (figs. 13, 14). Ground water is available from open and interconnected fractures and joints that seldom extend more than $100 \mathrm{~m}$ in depth. Yields to wells generally are less than $0.3 \mathrm{~L} / \mathrm{s}$. Exceptions are the upper Turpentine Run Basin on St. Thomas and the upper Guinea Gut Basin on St. John, where yields to wells of $6 \mathrm{~L} / \mathrm{s}$ and $1 \mathrm{~L} / \mathrm{s}$, respectively, have been obtained.

The quality of the ground water in both islands is strongly influenced by dissolved-solids content in rainfall; the chemical constituents are concentrated on the land surface and in the soil zone, carried into the aquifer during recharge, and further concentrated by evapotranspiration from the aquifer. The water is a sodium bicarbonate type, containing dissolved solids commonly greater than $1,000 \mathrm{mg} / \mathrm{L}$ and a chloride concentration of about $300 \mathrm{mg} / \mathrm{L}$.

\section{WATER BUDGET AND WATER USE}

A generalized water budget for each of the groundwater provinces of Puerto Rico, for the offshore islands of Vieques, Culebra, and Mona, and for the U.S. Virgin Islands is given in table 4.

The significance of ground-water sources in relation to other water sources in Puerto Rico and the U.S. Virgin Islands may be inferred from the diagrams in figures 15 and 16. In Puerto Rico in 1975, ground-water resources constituted about 40 percent of the total freshwater usage (excluding surface water used for hydroelectric power generation and for cooling at sugar mills), whereas in the U.S. Virgin Islands ground water provided 72 percent of freshwater usage (excluding desalinated water and recharged ground water at St. Croix). Of the total ground-water extraction in Puerto Rico in 1975, agriculture used 53 percent, industry 29 percent, and public water supply 18 percent. In the U.S. Virgin Islands ground-water extraction is almost all for domestic use and is about equally distributed between private wells and public water-supply systems.

The estimated total freshwater withdrawals in Puerto Rico to the year 2000 are shown in figure 17A. The decline in water withdrawals by industry and agriculture at Puerto Rico between 1960 and 1975 is 


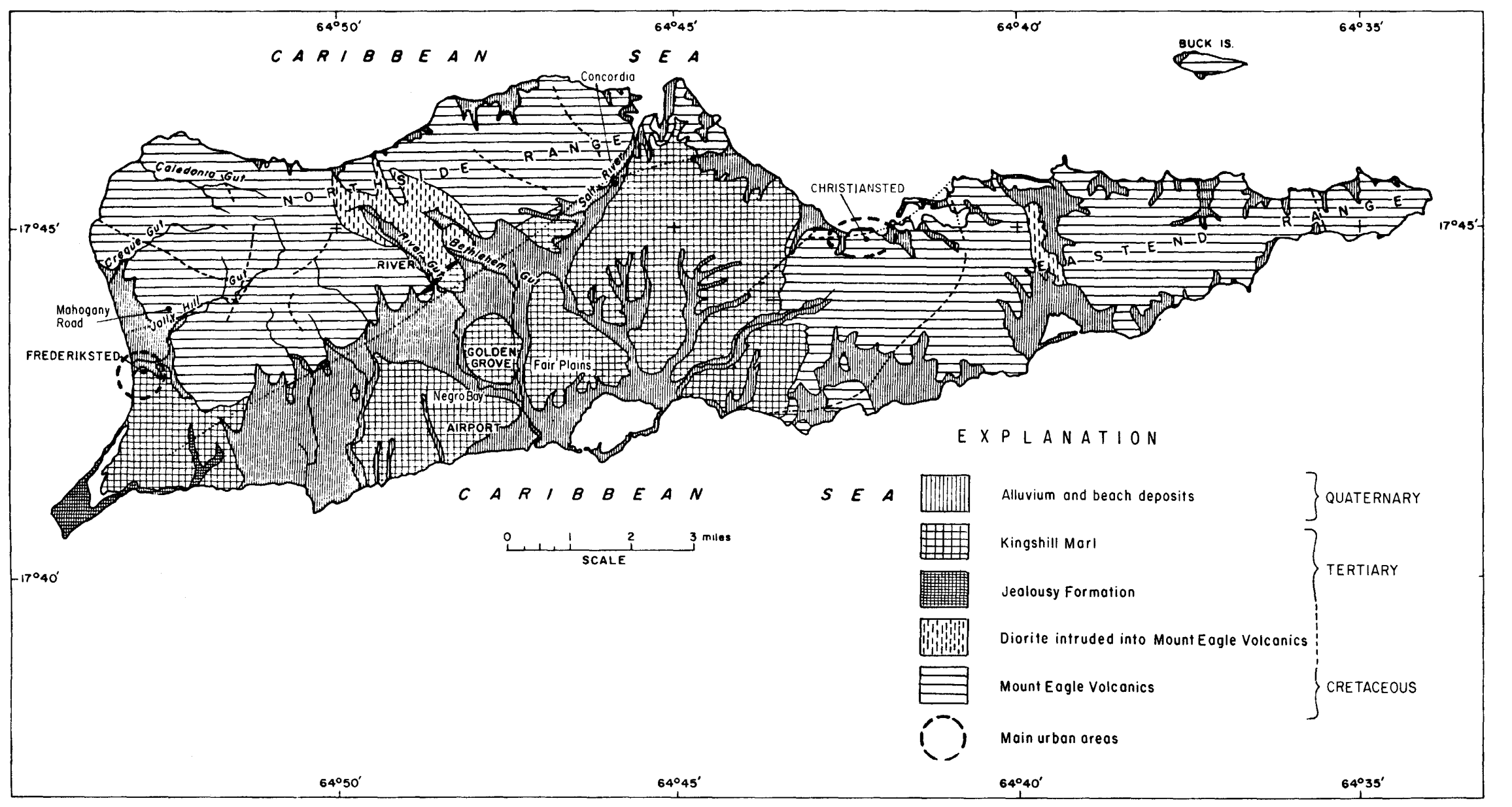

FIGURE 12. - Generalized geology of St. Croix, U.S. Virgin Islands (modified from Cederstrom, 1950, pl. 1). 


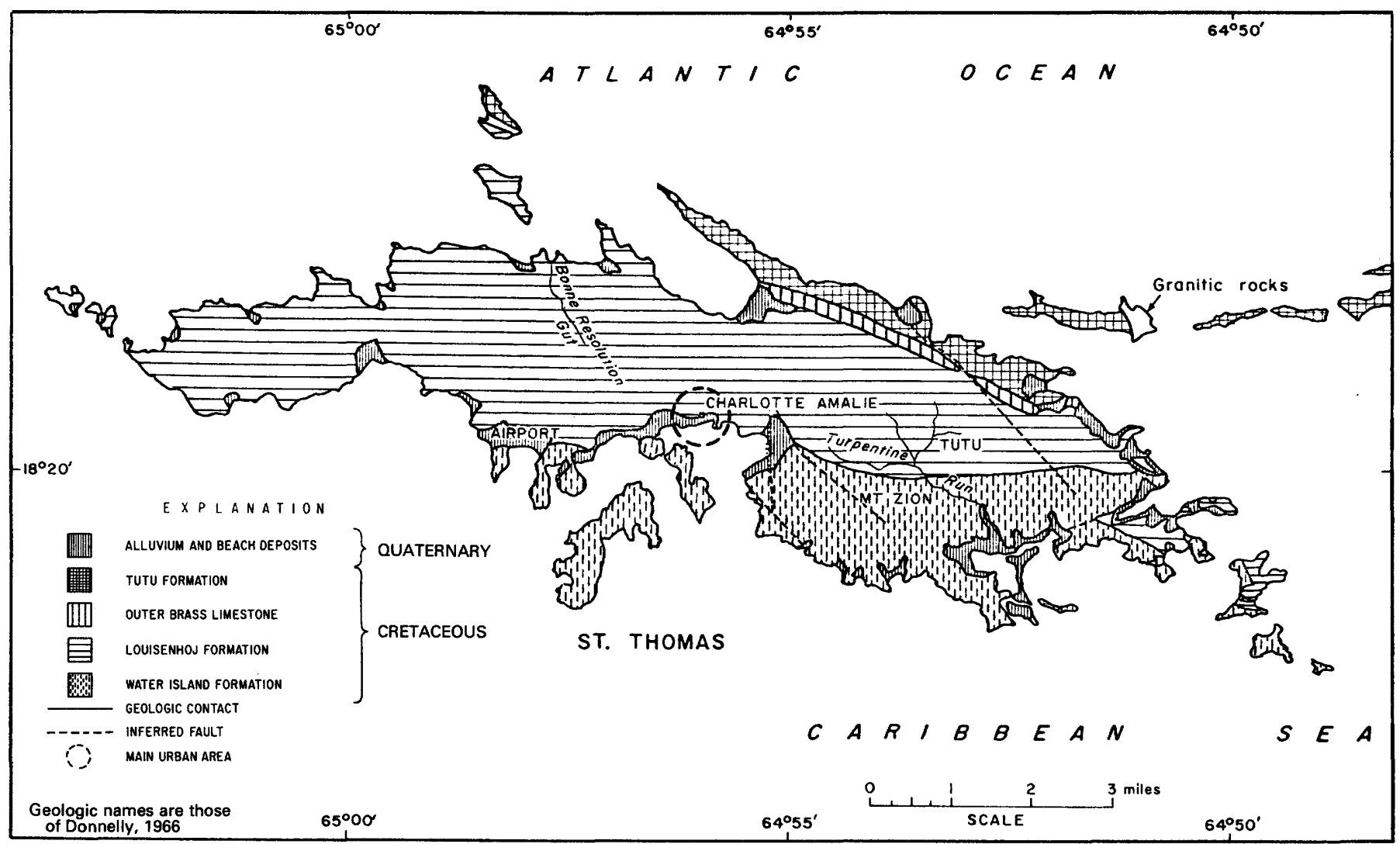

Figure 13. - Generalized geology of St. Thomas, U.S. Virgin Islands (modified from Jordan and Cosner, 1973)

directly related to the decline in sugar production and cessation of operations by sugar mills. During the same 15-year period, overall ground-water withdrawals remained about constant. Nevertheless, there was significant development of ground-water sources both for public supply and industrial use. Based on these trends and water use estimates, it seems very probable that by 1985 an additional $76 \mathrm{hm}^{3} / \mathrm{yr}$ will be obtained from the subsurface essentially for public supply ( 55 percent) and industrial use (45 percent). During the same period an additional $102 \mathrm{hm}^{3} / \mathrm{yr}$ of surface water flows are expected to be withdrawn for public supply. Agricultural water use is expected to remain at $345 \mathrm{hm}^{3} / \mathrm{yr}$ as a result of implementation of more efficient irrigation techniques. Projections of total freshwater withdrawals and category use beyond 1985 may have little significance, owing to the uncertain future of both the agricultural and industrial sectors.

Water needs in the U.S. Virgin Islands will rely heavily on desalination plants. Ground-water development throughout the islands is mostly limited to small- capacity wells tapping fractured rock to supply domestic needs. In central St. Croix, future development of the alluvium and limestone aquifer may be limited to less than $1.0 \mathrm{hm}^{3} / \mathrm{yr}$ under natural recharge conditions but could probably be expanded an additional $2.8 \mathrm{hm}^{3} / \mathrm{yr}$ (Morris, 1976) if artificial recharge of treated sewage effluent is fully implemented. The projected water needs in the U.S. Virgin Islands are given in figure $17 B$. Agricultural needs are essentially by livestock and are supplied from ponds. By 1985 livestock watering needs are not expected to be much greater than at present. Any irrigated agriculture may be expected to rely on effluent discharge at sewage-treatment plants. As in Puerto Rico, water needs projected past 1985 may be misleading. The role of ground water in public water supply in the Virgin Islands could be greater than expected if assessment of its saline-water reserves at St. Croix (less than $6,000 \mathrm{mg} / \mathrm{L}$ dissolved solids) proves to be on the order of $130 \mathrm{hm}^{3}$ (Robison, 1972) and if desalination by reverse osmosis or electrodialysis is economically feasible. 

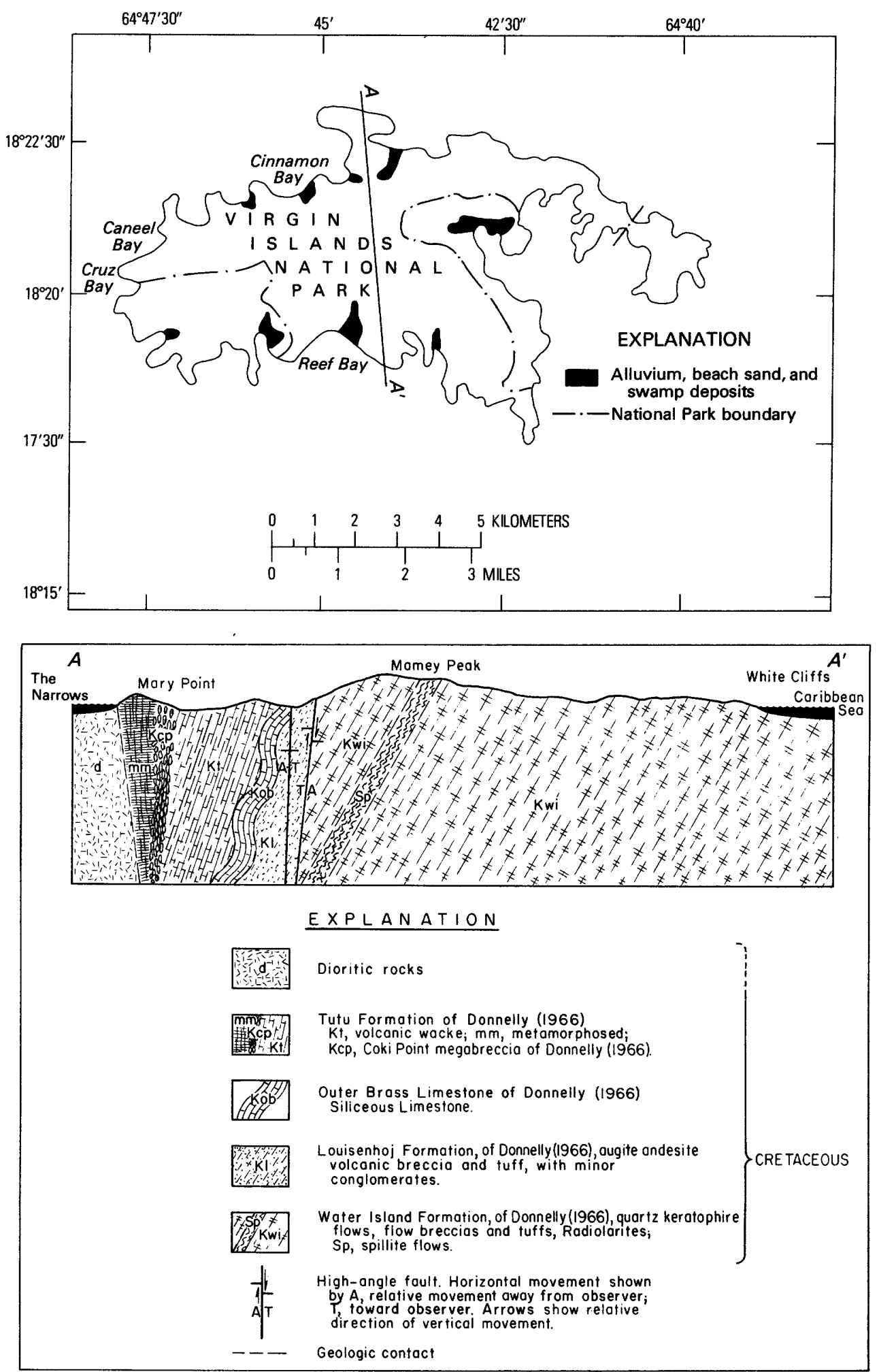

FIGURE 14. - Generalized geology of St. John, U.S. Virgin Islands 
ATMOSPHERE

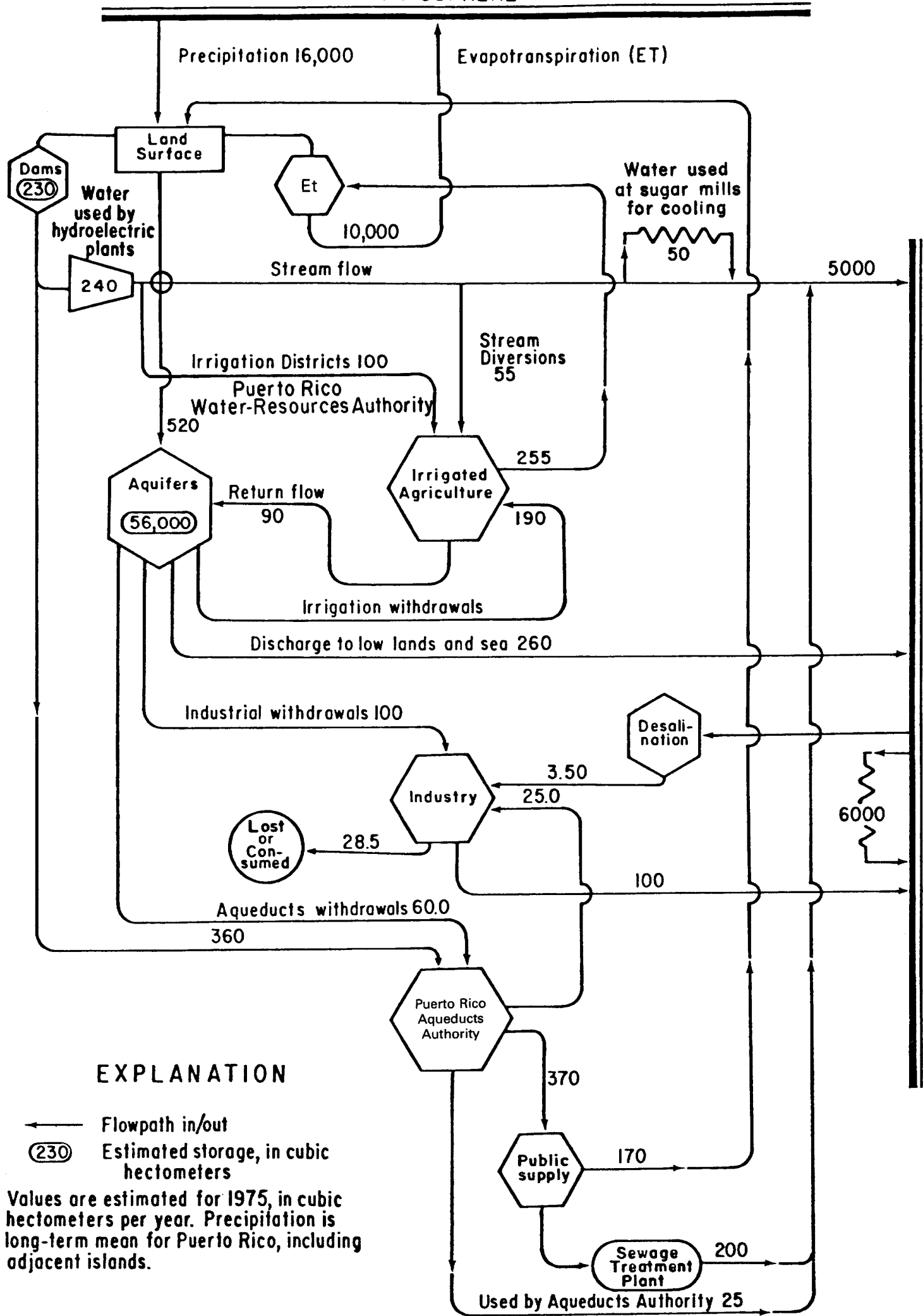

FIGURE 15. - Generalized water budget for Puerto Rico and its offshore islands. Values are estimated for 1975 (rounded to two significant figures); precipitation is long-term mean for Puerto Rico and offshore islands. Et, evapotranspiration. 


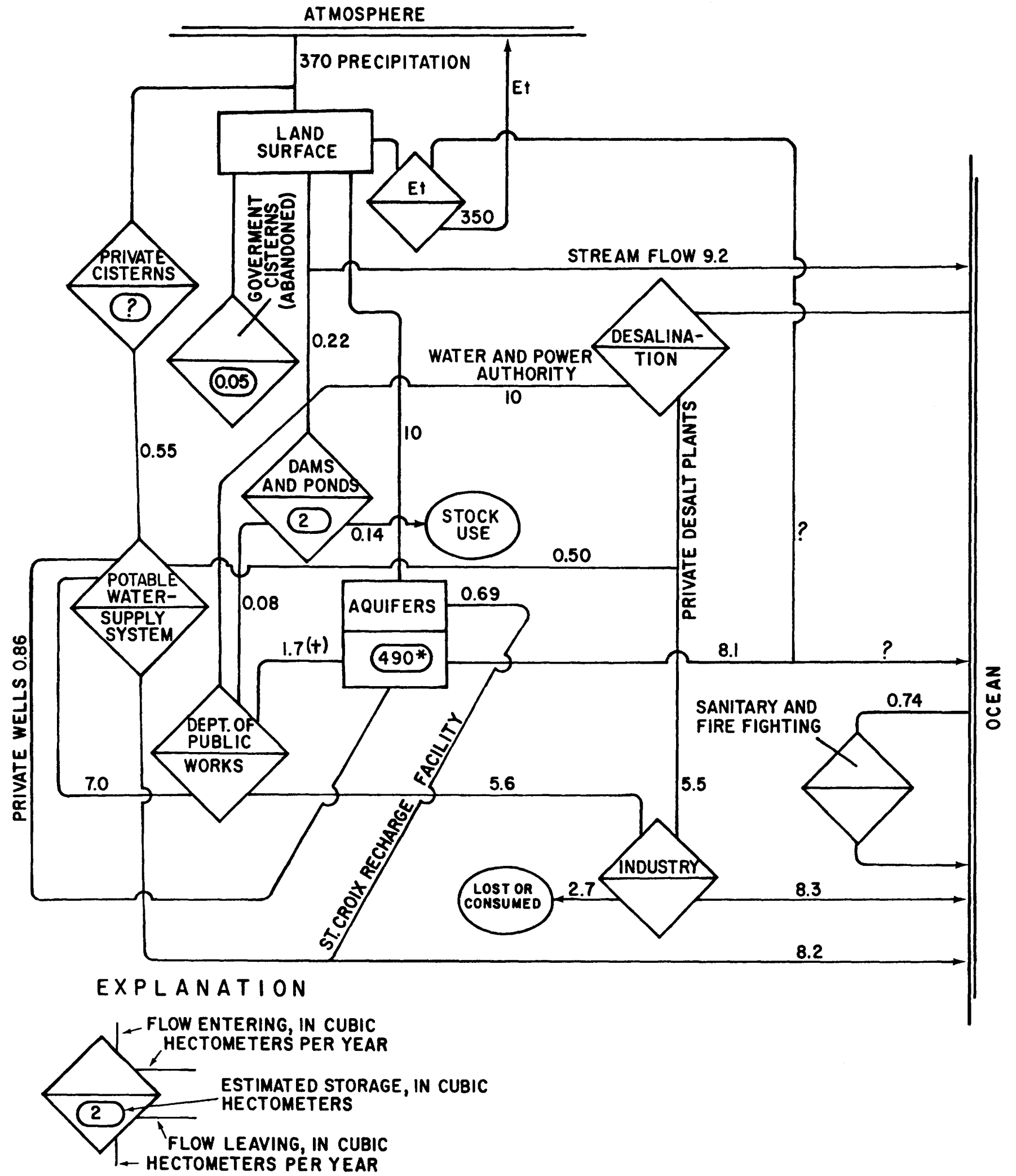

FIGURE 16. - Generalized water budget for U.S. Virgin Islands. Values are estimated for 1975 (rounded to two significant figures); precipitation is long-term mean. Et, evapotranspiration; dagger $(\dagger)$, value given assumming recharge operations and 85 percent recovery at St. Croix; asterisk $\left({ }^{*}\right)$, estimated storage for unconsolidated sediments only for central St. Croix. 
TABLE 4. - Water budget, in cubic hectometers per year ( $\left.\mathrm{hm}^{3} / \mathrm{yr}\right)$ and percent, for Puerto Rico (by

\begin{tabular}{|c|c|c|c|c|c|c|c|c|c|c|c|c|c|c|}
\hline & \multicolumn{14}{|c|}{ Puerto Rico } \\
\hline & \multicolumn{6}{|c|}{ North Coast Province } & \multicolumn{4}{|c|}{ South Province } & \multirow{2}{*}{\multicolumn{2}{|c|}{$\begin{array}{l}\text { Lajas } \\
\text { Valley }\end{array}$}} & \multirow{2}{*}{\multicolumn{2}{|c|}{$\begin{array}{l}\text { West Coast } \\
\text { province }\end{array}$}} \\
\hline & \multicolumn{2}{|c|}{$\begin{array}{l}\text { West coast to } \\
\text { Río Grande } \\
\text { de Arecibo }\end{array}$} & \multicolumn{2}{|c|}{$\begin{array}{c}\text { Río Grande de } \\
\text { Arecibo to Río } \\
\text { de La Plata }\end{array}$} & \multicolumn{2}{|c|}{$\begin{array}{c}\text { Río de La } \\
\text { Plata to Río } \\
\text { Espiritu Santo }\end{array}$} & \multicolumn{2}{|c|}{$\begin{array}{c}\text { Patillas } \\
\text { to } \\
\text { Ponce }\end{array}$} & \multicolumn{2}{|c|}{$\begin{array}{c}\text { Tallaboa } \\
\text { to } \\
\text { Guanica }\end{array}$} & & & & \\
\hline & $\mathrm{hm}^{3} / \mathrm{yr}$ & Percent & $\mathrm{hm}^{3} / \mathrm{yr}$ & Percent & $\mathrm{hm}^{3} / \mathrm{yr}$ & Percent & $\mathrm{hm}^{3 / \mathrm{yr}}$ & Percent & $\mathrm{hm}^{3} / \mathrm{yr}$ & Percent & $\mathrm{hm}^{3} / \mathrm{yr}$ & Percent & $\mathrm{hm}^{3 / \mathrm{yr}}$ & Percent \\
\hline \multicolumn{15}{|c|}{ Input } \\
\hline Precipitation & 1,680 & 73.0 & 1,280 & 55.4 & 670 & 53.2 & 410 & 50.6 & 60 & 25.5 & 100 & 72.8 & 360 & 29.0 \\
\hline Streamflow _- & 620 & 27.0 & 1,030 & 44.6 & 590 & 46.8 & 320 & 39.5 & 175 & 74.5 & 4.4 & 3.2 & 880 & 71.0 \\
\hline Diversions ___ & - & $-\ldots$ & -- & --- & --- & --- & 80 & 9.9 & --- & --- & 33 & 24.0 & --- & --- \\
\hline \multicolumn{15}{|c|}{ Output } \\
\hline Evapotraspiration & 1,410 & 61.3 & 804 & 34.8 & 300 & 23.8 & 430 & 53.1 & 60 & 25.5 & 120 & 87.3 & 270 & 21.8 \\
\hline Stream outflow -...-. & 865 & 37.6 & 1,360 & 58.9 & 920 & 73.0 & 190 & 23.5 & 100 & 42.6 & 11 & 8.0 & 920 & 74.2 \\
\hline $\begin{array}{l}\text { Ground-water loss to } \\
\text { wetlands or sea }\end{array}$ & & & & & & & & & & & & & & \\
\hline $\begin{array}{l}\text { wetlands or se } \\
\text { Ground-water } \\
\text { withdrawals }{ }^{1} \text { : }\end{array}$ & 15 & .7 & 86 & 3.7 & 20 & 1.6 & 20 & 2.5 & 15 & 6.4 & 6.3 & 4.6 & 40 & 3.2 \\
\hline Total & 10 & .4 & 60 & 2.6 & 20 & 1.6 & 170 & 21.0 & 60 & 25.5 & .1 & .1 & 10 & .8 \\
\hline Industry & 9 & $\ldots$ & 26 & ---- & 5 & --_- & 19 & .... & 21 & --_- & ---- & $\ldots$ & 10 & $\ldots$ \\
\hline Irrigation & --_- & - & 8 & --- & --_ & $\ldots$ & 143 & -..- & 37 & --- & $-\ldots$ & ---- & --- & --- \\
\hline Public supply _._. & 1 & $\ldots$ & 26 & --- & 15 & $\ldots$ & 8 & $-\cdots$ & 2 & ---- & ---- & $\ldots$ & ---- & --.- \\
\hline
\end{tabular}

${ }^{1}$ All ground water withdrawn was assumed to be for consumption since it is not available for other uses.

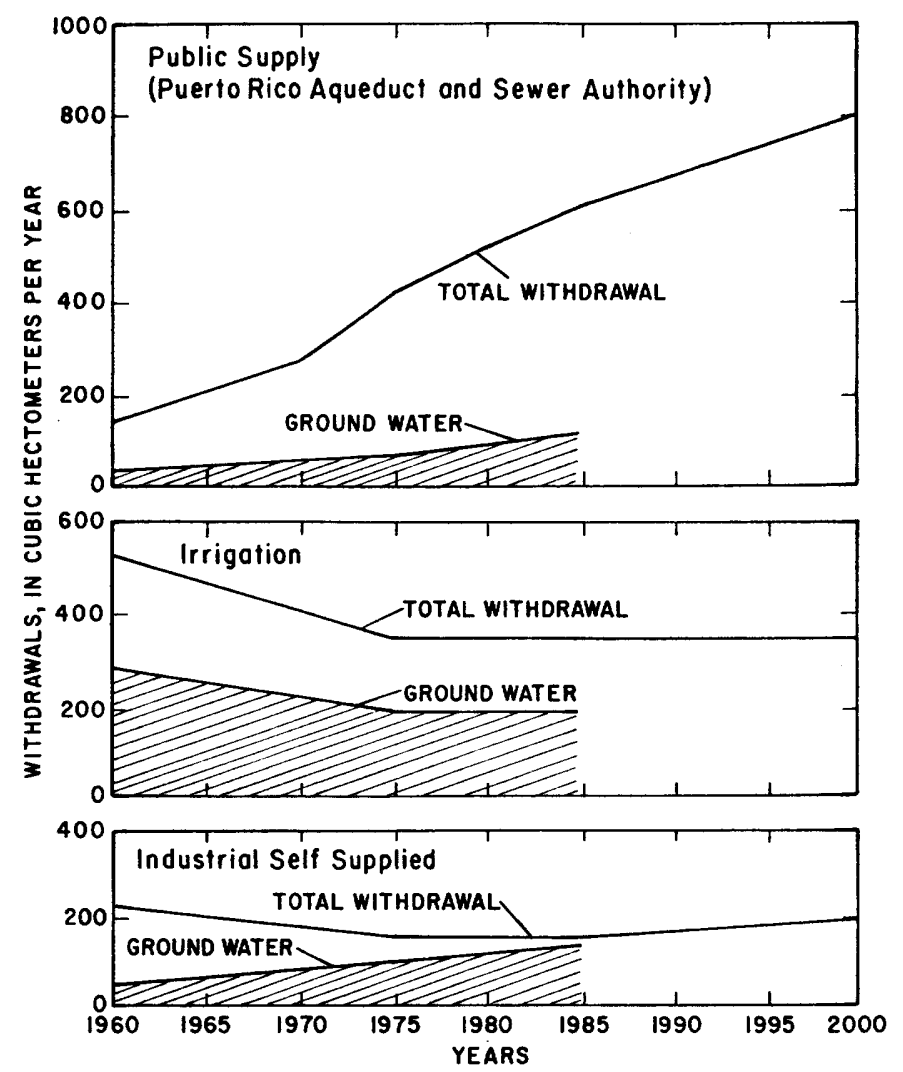

$A$

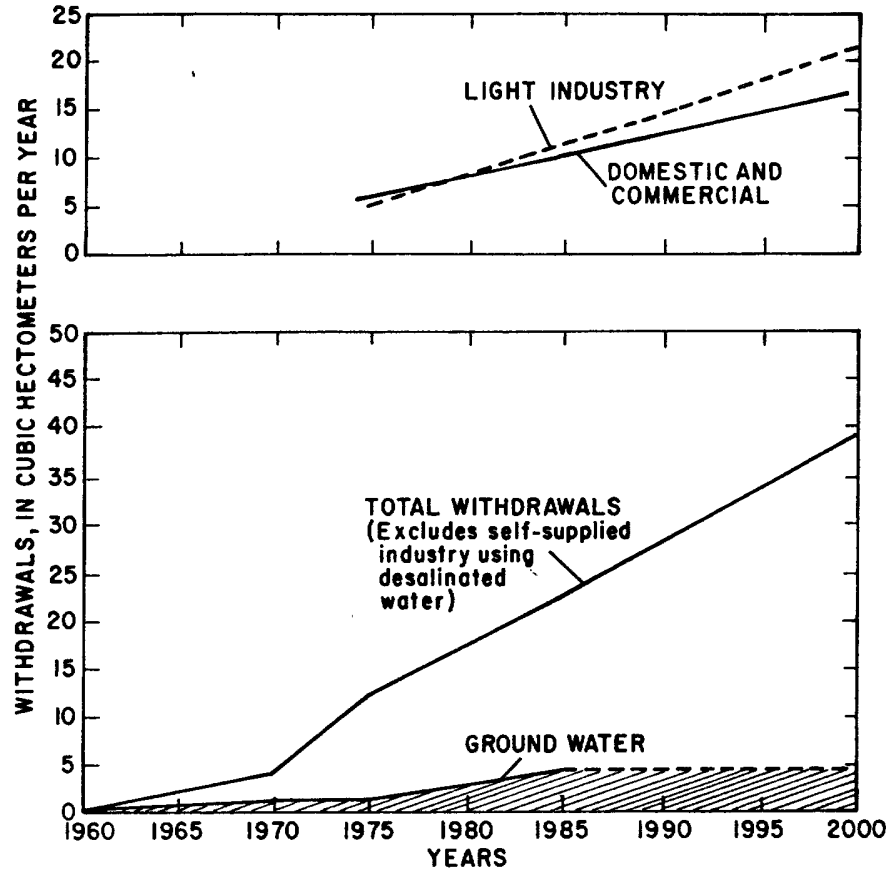

$B$

FIgure 17. - Water-use estimates. A, For Puerto Rico; public-supply data provided by the Puerto Rico Aqueduct and Sewer Authority (modified from Morris, 1976). $B$, For the U.S. Virgin Islands. 
province) and its offshore islands (Vieques, Culebra, and Mona Islands) and for the U.S: Virgin Islands, 1975

\begin{tabular}{|c|c|c|c|c|c|c|c|c|c|c|c|c|c|c|c|c|c|}
\hline \multicolumn{12}{|c|}{ Puerto Rico-Continued } & \multicolumn{6}{|c|}{ U.S. Virgin Islands } \\
\hline & & & & & & & Puert & Rico's o & fshore isla & & & \multirow{2}{*}{\multicolumn{2}{|c|}{ St, Croix }} & \multirow{2}{*}{\multicolumn{2}{|c|}{ St. Thomas }} & \multirow{2}{*}{\multicolumn{2}{|c|}{ St. John }} \\
\hline \multicolumn{2}{|c|}{$\begin{array}{c}\text { East Coast } \\
\text { province }\end{array}$} & \multicolumn{2}{|c|}{$\begin{array}{l}\text { Interior } \\
\text { province }\end{array}$} & \multicolumn{2}{|c|}{$\begin{array}{l}\text { Puerto Rico } \\
\text { Island total }\end{array}$} & \multicolumn{2}{|c|}{ Vieques } & \multicolumn{2}{|c|}{ Culebra } & \multicolumn{2}{|c|}{ Mona } & & & & & & \\
\hline $\mathrm{hm}^{3} / \mathrm{yr}$ & Percent & $\mathrm{hm}^{3 / \mathrm{yr}}$ & Percent & $\mathrm{hm}^{3} / \mathrm{yr}$ & Percent & $\mathrm{hm}^{3 / \mathrm{yr}}$ & Percent & $\mathrm{hm}^{3 / y r}$ & Percent & $\mathrm{hm}^{3} / \mathrm{yr}$ & Percent & $\mathrm{hm}^{3} / \mathrm{yr}$ & Percent & $\mathrm{hm}^{3} / \mathrm{yr}$ & Percent & $\mathrm{hm}^{3} / \mathrm{yr}$ & Percent \\
\hline \multicolumn{18}{|c|}{ Input-Continued } \\
\hline 390 & 43.3 & 10,870 & 100 & 15,820 & 100 & 120 & 100 & 25 & 100 & 45 & 100 & 220 & 100 & 95 & 100 & 55 & 100 \\
\hline 510 & 56.7 & --- & --- & $-\ldots$ & - & $\ldots$ & $-\infty$ & -- & - & $\ldots$ & $\ldots$ & $\ldots$ & $\ldots$ & --- & $-\infty$ & - & --- \\
\hline$+\cdots$ & --- & $-\cdots--$ & ---- & --- & --- & --- & --- & $\cdots$ & --- & --- & --- & ---- & ---- & ---- & ---- & ---- & ---- \\
\hline \multicolumn{18}{|c|}{ Output-Continued } \\
\hline 278 & 31.0 & 6,512 & 59.9 & 10,156 & 64.2 & 110 & 91.7 & 24.0 & 95.8 & 39.5 & 87.8 & 205 & 93.2 & 91 & 95.8 & 54 & 98.2 \\
\hline 580 & 64.4 & 4,342 & 39.9 & 5,046 & 31.9 & 6 & 5.0 & .7 & 2.8 & 0 & 0 & 8 & 3.6 & 2.6 & 2.7 & .4 & .7 \\
\hline 30 & 3.3 & $\ldots$ & ---- & 260 & 1.6 & 3.3 & 2.7 & .3 & 1.2 & 5.5 & 12.2 & 5.5 & 2.5 & 1.2 & 1.3 & .6 & 1.1 \\
\hline 12 & 1.3 & 16 & .2 & 358 & 2.3 & .7 & .6 & .04 & .2 & 0 & 0 & 1.5 & .7 & .2 & .2 & -... & 0 \\
\hline 10 & -..- & 4 & --- & 104 & -.. & -... & ---- & --.- & …. & --- & -..- & $\cdots$ & $-\cdots$ & - & $-\ldots$ & -... & $-\infty$ \\
\hline--- & $-\cdots$ & ---- & ---- & 188 & ---- & --- & ---- & -- & $-\cdots$ & --- & $-\cdots$ & $\cdots$ & $\ldots$ & $+\cdots$ & $\cdots$ & -- & --- \\
\hline 2 & --- & 12 & ---- & 66 & - & +-- & ---- & $\ldots$ & $\rightarrow$ & -.. & $\cdots$ & --- & $\cdots$ & --- & $\ldots$ & $\cdots$ & -... \\
\hline
\end{tabular}

\section{PROBLEMS AFFECTING USE OF WATER RESOURCES}

MANAGEMENT-PUERTO RICO

By adoption of Law No. 23 of January 1973, the Puerto Rico Department of Natural Resources (DNR) was charged with the responsibility for implementation of the operational phase of the public environmental policy of Puerto Rico. Law No. 23 also provides for centralization of operational functions and implementation of regulations that had previously been dispersed throughout many governmental agencies. In addition, the new Water Law, No. 136 of June 3, 1976, assigned to the Secretary of DNR the responsibility to plan and regulate the use of and to improve, conserve, and develop the waters of Puerto Rico. In acknowledgment of the need for a centralized information center, the new water law also stipulates that the Secretary be assisted by a staff that has representatives from the Planning Board, the Puerto Rico Industrial Development Company (PRIDCO), the Environmental Quality Board (EQB), the Puerto Rico Aqueduct and Sewer Authority (PRASA), the Puerto Rico Water Resources Authority (PRWRA), the Department of Agriculture (DOA), the Department of Health (DOH), the Department of Transportation and Public Works, and the University of Puerto Rico.

Although numerous government agencies (State and Federal) and institutions are involved in the use, planning, management, and investigation of the water resources, the DNR, EQB, U.S. Environmental Protection Agency (EPA), PRWRA, PRASA, Puerto Rico Sugar Corporation, and heavy water-use industries established by PRIDCO exert the greatest influence over the future of this resource. The responsibilities these agencies and public corporations have with respect to water resources are listed as follows:

DNR. The functions of this Puerto Rican agency were established by Laws No. 23 and No. 136, previously stated.

EQB. This is the Puerto Rico policy-making and regulatory agency responsible for the enhancement and protection of water quality; it is invested with quasijudicial powers to enforce its regulations. For purposes of the Federal Water Pollution Control program (Public Law 92-500) the Board is designated the State water-pollution control agency.

EPA. This is the Federal agency charged with administration of Public Law 92-500 aimed at restoring and maintaining the chemical, physical, and biological integrity of the Nation's waters. Among the programs the agency administers are establishment of effluent limitations, administration of the National Pollutant Discharge Elimination System, and management and planning for public watersupply treatment-works construction.

PRWRA. The authority produces and distributes electrical energy and administers and operates the irrigation systems supported by releases from reservoirs and the hydroelectric power-generation network on the south coast and in northwestern Puerto Rico.

PRASA. The authority is charged with development, construction, operation, and maintenance of water and sewer systems and providing adequate water 
and sewer services and any other related services and facilities.

Puerto Rico Sugar Corporation. A public corporation created by legislative action in 1973 to consolidate the operations of the sugar industry (cultivation and refining). The corporation manages all the 11 mills on the island, 7 of which are government owned. The corporation also manages cane cultivation on 29,600 ha of both government-owned and leased land.

PRIDCO. This is the principal Puerto Rico governmental agency charged with the responsibility for the economic development of Puerto Rico. With its associated public corporation, the Government Development Bank, it devises methods to accelerate economic development, especially through industrial promotion and tourism. This agency must submit to $\mathrm{DNR}$ and EQB an environmental-impact statement for each industrial project it proposes to develop. The agency also cooperates closely with the Planning Board in preparing its plans and programs.

The new centralized form of management stipulated in Law No. 136 of June 3, 1976, is intended to improve institutional structures to aid optimum water-resources development.

\section{MANAGEMENT - U.S. VIRGIN ISLANDS}

In the U.S. Virgin Islands, the Department of Conservation and Cultural Affairs is charged with the administration and enforcement of all laws relating to water resources and water pollution, under Title 3 , Chapter 22, of the Virgin Islands Code as of June 4, 1968. Other agencies involved with the management of the water resources are the Public Works Department, the Water and Power Authority, and the Virgin Islands Planning Office. The functions of each of these are outlined as follows:

Public Works Department. Under Title 30, Section 51, of the Virgin Islands Code, the Commissioner of Public Works is designated to supervise and control the construction, repair, maintenance, operation, and administration of the potable-water systems. The potable-water system was defined as "all fresh water stored or collected by the government, whether in catchments, dams, wells, or reservoirs, for public distribution."

Virgin Islands Water and Power Authority (WAPA). This authority was established in 1964 under Virgin Islands Code, Section 103, Title 30, for production and distribution of electrical energy and provision of potable water from its water-distillation systems. In the enabling legislation is a provision, $104 \mathrm{e}$, for the transfer of the water-supply functions of the Public
Works Department to WAPA at a date to be determined by law. The transfer of functions has not been acted upon by the legislature, and WAPA sells the distilled water to the Public Works Department.

U.S. Virgin Islands Planning Office. This office is designated as the government agency in charge of water-management planning; the agency is also entitled to appropriate funds received under the title 3 program.

The Public Works Department is by far the major ground-water user. Agriculture is almost nonexistent in the islands, and industries that depend heavily on water obtain their water from self-owned desalination plants. For these reasons, a lack of coordination among water users is not a major problem affecting ground-water resources in the Virgin Islands.

\section{WATER RIGHTS}

Water rights and laws regulating water use have been established by society to assure the minimum requirements of individuals and communities, to promote the beneficial development of water resources, and to respect legal access to water sources. These laws, which have been implemented to reduce friction between users, ironically become constraints if they are not adapted to the needs of a modern technological society.

On June 3, 1976, the Commonwealth Legislature approved the Law of Waters (Law No. 136) for Puerto Rico, which declared all waters within Puerto Rico the patrimony and wealth of the People of Puerto Rico; endowed the Secretary of Natural Resources with the power to plan and regulate the use, conservation, and development of the water resources and to implement the public policy and regulations related to the waters of Puerto Rico; and annulled two provisions of the Civil Code and the Law of Waters of March 12, 1903.

The 1903 water law was essentially that which had been in effect in Spain since 1879 and had been extended over Puerto Rico by order of the King in 1886. Article 16 of Law No. 136 recognized acquired rights that make beneficial and reasonable use of water and were in existence prior to June 3, 1976, including those concessions from the Spanish Crown.

Acquired rights under the old Spanish law were obtained according to the prior-appropriation doctrine. For example, "any landowner may utilize the pluvial and other waters flowing intermittently in public channels or along roads" (Art. 6, 176, 177); "after use for one year and a day, he establishes a temporary right that is superior to that of any subsequent user," on the principle that first in time is first in right (Art. 7); "after water has been used without interruption for 20 years, the appropriator acquires the right to continue the use indefinite- 
ly" (Art. 8). Similarly, as to "artesian wells, tunnels, or galleries," (major ground-water developments as opposed to "ordinary wells," which are defined (Art. 20) as those for which no other motive power than man is employed for raising the waters), the right of the person discovering and bringing the water to the surface is recognized "in perpetuity," as long as such development does not interfere with preexisting rights to public or private waters (Art. 23). These rights (surface- or ground-water appropriation) were also recognized for all individuals who had enjoyed the use of public waters for a period of 20 years (prior to 1886) even though no proper authorization had been obtained.

The order of preference in utilization stipulated by the previous law (Art. 160 of the Spanish Water Law) expressed the needs of the past century. First priority was given to water supply of towns, followed by water supply of railroads, irrigation, navigational canals, mills and other factories, ferry boats and floating bridges, and fishponds. The economic importance of water-using industries was not foreseen, and a low preference as to water concessions was stipulated. Duration of the concessions was limited to 99 years of town supplies (Art. 170) and all other uses but was "in perpetuity" for irrigation (Art. 188) and fishponds and also for industry, as long as effluents were not harmful to health or vegetation (Art. 220).

As of 1909 there were approximately 250 concessions in Puerto Rico that were originally granted by the Spanish Crown (Report of the Governor of Puerto Rico, 1909). The majority of these grants were given to landowners in the South Coast province for the irrigation of approximately 21,000 ha. The surface-water concessions included rights to flood-waters, spring and winter waters, or a definite daily flow.

An updated inventory of vested owners, diversion amounts, and land under irrigation is necessary to determine the degree to which these rights could affect a water-use and distribution plan.

In the Virgin Islands, all waters are in public ownership and are subject to appropriation for beneficial use as stipulated in Chapter 5, Title 12, of the Virgin Islands Code. Under this policy, vested rights are recognized prior to other appropriation. Vested rights may be nullified by the government of the Virgin Islands (Commissioner of Conservation and Cultural Affairs) when it is determined that the exercise of such rights would imperil health or welfare by endangering, impairing, or destroying available sources of water. Nevertheless, the occurrence of such circumstances is very remote, as most private installations are for domestic use and withdraw less than $2 \mathrm{~m}^{3} / \mathrm{d}$. An exception could be those individuals and companies that sell water obtained from wells. Under Section 153 of Title 12, appropriation per- mits are not required if pumpage is less than $2 \mathrm{~m}^{3} / \mathrm{d}$ for beneficial use.

Under Chapter 3, Title 12, of the Virgin Islands Code, trees and other vegetation adjacent to watercourses are protected by law. This regulation protects the esthetic values of stream channels but results in a significant loss of ground water to evapotranspiration by the deeprooted vegetation. A modification of this law would be necessary in order to exclude from such provision those watercourses that are used for public supplies or are in hydraulic connection with aquifers tapped for supply.

\section{PRACTICES DETRIMENTAL TO GROUND-WATER QUALITY}

\section{LAND USE}

Land use may affect recharge to an aquifer and the quality of its water. Although there has been no extensive evaluation of the effects of various land uses on aquifers in the Caribbean Region, data from scattered sources indicate that this could be a major problem in the near future.

Urbanization has taken over large portions of the recharge areas of aquifers in metropolitan San Juan, Ponce, and Mayagüez in Puerto Rico and throughout the Virgin Islands of St. Croix and St. Thomas. Unless artificial recharge is provided or withdrawals are reduced to compensate for the loss of recharge, the seawaterfreshwater interface will move inland in most of these areas.

Aquifers in the Caribbean Region are threatened by pollution from domestic, municipal, and industrial sources. The most widespread source of pollution is probably sewage from cesspools, leaking sewage lines, and overloaded or improperly operating sewage plants. In Puerto Rico about 37 percent of the population is served by sewers, and in the U.S. Virgin Islands approximately 77 percent is served. In general, the only areas served by sewers are those within the urban limits of towns.

Industrial wastes have been discharged to aquifers through sinkholes and disposal wells or have entered aquifers from accidental spillage (D.G. Jordan, written commun., 1969; R.C. Vorhis, written commun., 1972). Of the 15 disposal wells known to exist in 1972 , only 2 could be designated as deep injection wells, and the others could better be designated waste-disposal holes. All the known disposal holes were between 24 and $213 \mathrm{~m}$ deep. Wastes disposed in sinkholes and disposal holes include sewage, oil, neutralized acid, organic compounds, dyes, pickling liquors, pineapple-cannery wastes, and brewery wastes. Jordan (written commun., 1969) estimated there were at least 40 such disposal holes in Puerto Rico in 1969.

It has also been observed that unproductive wells are either abandoned without plugging or are not thor- 
oughly sealed. As a result many are used as receptacles for wastes. The effects on water quality and the extent of damage this has caused in the Caribbean Region have not been assessed. In the Lajas Valley, Vazquez and Ortiz-Velez (1967) observed that a downward hydraulic gradient existed at various abandoned irrigation wells. These wells probably are serving as hydraulic connectors between perched water tables and the underlying regional water table. The effect of these "hydraulic connectors" on water quality is unknown.

Disposal of refuse in landfills poses another threat to aquifers in Puerto Rico. Most landfills were estalished after 1972 (fig. 18), and although migration of leachates may be slow at some sites, with time these will inevitably affect to some degree the local ground-water sources. In the U.S. Virgin Islands, landfills have been established near the coast on St. Croix and St. Thomas, and contamination of freshwater sources is not a threat. The landfill on St John, however, is located in the in- terior Guinea Gut Basin, where potential for groundwater development exists.

\section{IRRIGATION PRACTICES}

Irrigation of crops occurs primarily in southern Puerto Rico. The basic means of distributing water within cultivated lands is by furrows, although overhead sprinklers are used at some farms in the early months of sugarcane cultivation. Giusti (1971) estimated that approximately 30 percent of the applied water in the South Coast province (Coamo area) was recharged to the aquifer. Bennett (1976) indicated that the ground-water reservoir in the South Coast province is "vertically oriented," in that local recharge and discharge tend to be high in any given locality relative to lateral groundwater flow. In areas where irrigation water is derived from wells, recycling of the irrigation water will result in an increase in the dissolved-solids concentration of the ground water.
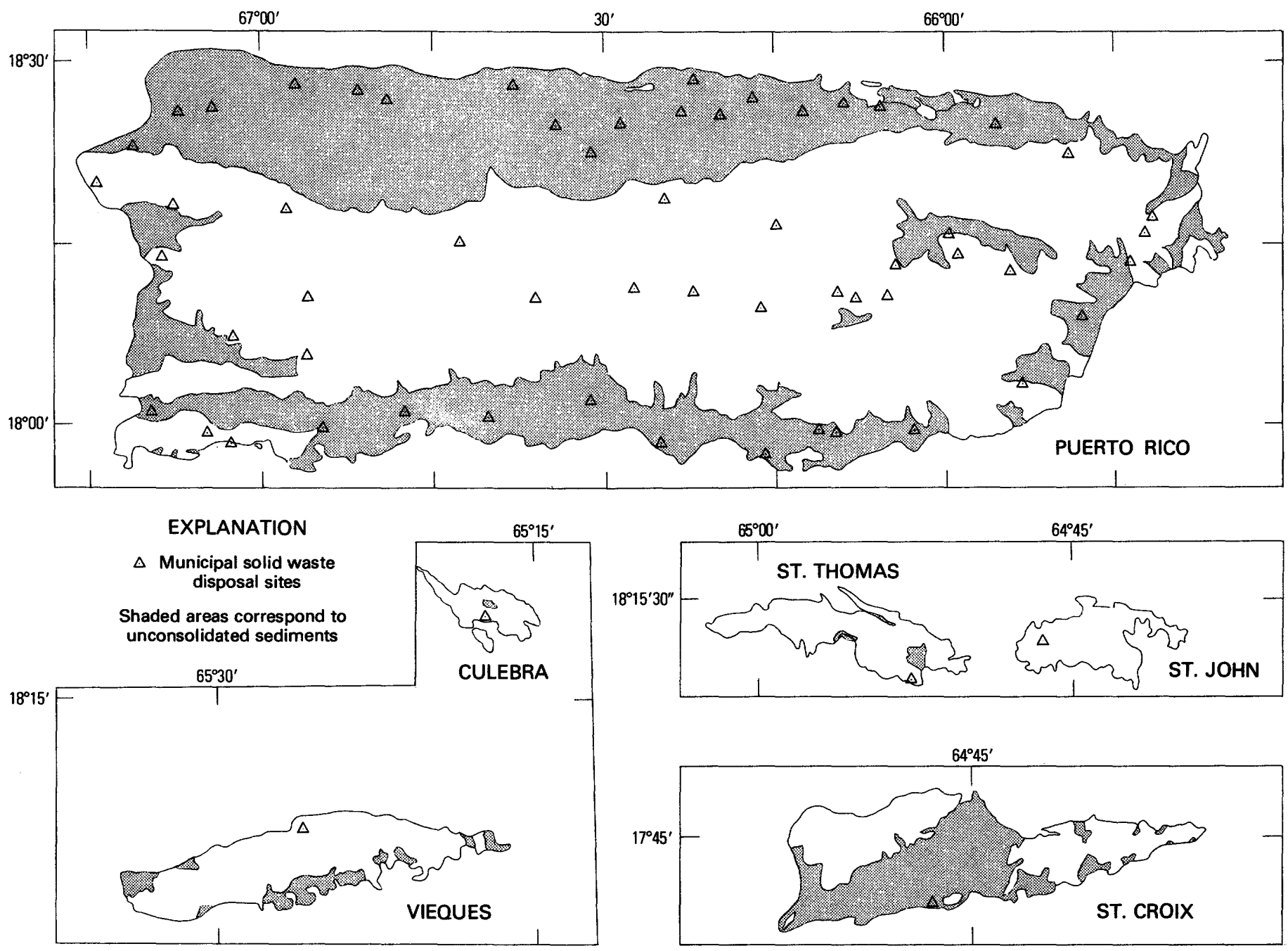

FIGURE 18. - Solid-waste disposal sites in the Caribbean Region. 
During the mid-1960's, drought nearly eliminated surface-water supplies that were used in the South Coast province area for irrigation, and ground-water production was increased to make up the deficit. By 1968 , after 3 years of increased pumpage, the ground water in storage was drastically depleted. An estimated $1,000 \mathrm{hm}^{3}$ of the $1,500 \mathrm{hm}^{3}$ in available storage had been withdrawn. The depletion in storage was accompanied by a decline in ground-water levels to below seá level over large areas (pl. 1A). The chloride concentration in the ground water increased slightly in the more severely depleted areas, but major seawater intrusion did not occur, apparently because of a slight ground-water mound in the coastal areas and the lower hydraulic conductivity of the coastal part of the aquifer. Heavy rains later in 1968 recharged the aquifer, but it has never recovered to early 1960 levels. A few areas where ground-water levels were below sea level still persisted in 1976 (pl. $1 B$ ), but there has been no significant increase in chloride concentration indicative of seawater intrusion.

\section{OPTIMIZATION OF USE OF WATER RESOURCES}

In general, until recent years the effort devoted to optimizing the use of water resources of the Caribbean Region has been minimal. Within Puerto Rico this lack of effort may have been due to the relative abundance of freshwater in relation to demand in most areas. In the U.S. Virgin Islands the poor quality of the ground water and the knowledge that the limited freshwater resources could not meet the demand led to reliance on seawaterdesalination plants.

Two major approaches are available for optimizing the use of water resources. These are conjunctive use of surface- and ground-water sources and water conservation. The potential for application of such measures in the Caribbean Region is discussed separately.

\section{CONJUNCTIVE USE OF SURFACE- AND GROUND-WATER SOURCES}

The greatest potential for conjunctive use of surfaceand ground-water sources in the Caribbean Region may be on the island of Puerto Rico, where both sources are relatively plentiful. This use may be achieved by reservoir management, augmenting natural recharge, ground-water salvage, ground-water mining, and use of seawater.

\section{RESERVOIR MANAGEMENT}

Agriculture is the largest single water user in the South Coast province. The estimated ground-water withdrawal for irrigation $\left(180 \mathrm{hm}^{3} / \mathrm{yr}\right)$ constitutes almost 80 percent of the total pumpage. Therefore, the most productive efforts to solve the "water shortage" may involve an improvement of irrigation practices. To some degree, the irrigation efficiency likely could be improved by coordinating the activities of PRWRA with those of the Puerto Rico Sugar Corporation and by changing the priority of the functions of reservoirs serving the south coast.

Under present operating conditions, reservoirs are maintained at the highest stage possible for hydroelectric generation, thus reducing the runoff-capture potential. With the available reservoirs and the implementation of a more efficient water-management system, more water could be made available for irrigation. The hydroelectric-energy loss could possibly be compensated for by thermoelectric generation through burning of bagasse, the plant residue left after the juice has been extracted from sugar cane. During the 1973 fiscal year, PRWRA bought from the sugar mills (which operate from about December to April) 826 million kilowatthours of energy generated through burning of bagasse (Puerto Rico Planning Board, 1976). Hydroelectric generation was only about 97.5 million kilowatt-hours during the 1973 fiscal year, partly by north-coast hydroelectric plants.

\section{AUGMENTING NATURAL RECHARGE}

Although aquifers receive recharge by natural means, it may be practical in some areas to increase this amount artificially. Within urbanized centers the loss of rainfall infiltration capacity may be compensated for by construction of infiltration ponds, which may also serve for recreation. Flow into the ponds could be supplied from urban runoff or by pumpage from nearby streams. These infiltration ponds could be situated in the upland coastal areas, where coarse sediments (sand and gravel) predominate and thickness of unsaturated material and therefore storage volume is greatest. Areas of Puerto Rico that could benefit most from such modifications are those zones where urban development has decreased the infiltration capacity of aquifers (essentially the San Juan metropolitan area and Ponce). In the San Juan metropolitan area, possible sites would be the San Sebastian outcrop and areas between the haystack hills (mogotes). At Ponce the most favorable area may be near the foothills, where depth to the water table is between 15 and $20 \mathrm{~m}$. Infiltration induced by this method may make it feasible to establish and continuously operate public-supply wells within city limits, thus reducing dependence on interbasin water transfer. These well fields would also be invaluable in the event of hurricane damage to centralized water-purification and distribution systems. If the recharged water is destined for domestic use, measures would have to be taken to avoid contamination with toxic substances, which may 
not be removed during infiltration through the soil column.

Infiltration ponds can be used only in areas where vertical soil permeability permits adequate rates of infiltration. If alluvial material is highly stratified or if more permeable zones occur at depth, it may be convenient to use recharge wells instead. If wells are utilized, the injection water would have to be of high quality, as the natural filtration and purification capacity of surface soils would be bypassed.

The chief uses of infiltration ponds or recharge wells may be to augment aquifer yields or to control seawater intrusion. The potential for using aquifers in the Caribbean Region as additional freshwater storage reservoirs is limited, as flow is continuously seaward and aquifers are small.

Freshwater runoff may also be retained in "coastal lakes" constructed parallel to the coast. These would serve as a natural barrier for controlling seawater intrusion by stabilizing the position of the seawaterfreshwater interface. A major site where this technique could be applied is at Laguna San Jose in metropolitan San Juan. Inland of the lagoon is an aquifer whose potential for yields to wells is greater than $35 \mathrm{~L} / \mathrm{s}$ (Anderson, 1976), but the brackish water at Laguna San Jose could be induced into the aquifer by overpumping. The brackish nature of the water is derived mainly from seawater entering through the canals during tidal flow. If the lagoon outlets are dammed, runoff from its $35-\mathrm{km}^{2}$ basin could probably replace the brackish water. The mean annual runoff received by the lagoon from its almost completely urbanized basin is not known, but a study by U.S. Geological Survey (Gómez-Gómez and S.R. Ellis, written commun., 1978) determined that the lagoon received 1.7 million $\mathrm{m}^{3}$ of inflow from am 8-hour, $70-\mathrm{mm}$ rainstorm over the basin. The lagoon's storage capacity is approximately 13 million $\mathrm{m}^{3}$. Additional amounts of freshwater could be made available to the lagoon from the nearby Río Grande de Loiza by providing the proper pumping facilities. If the lagoon can be converted to a freshwater body and if water-quality conditions can be improved, flow from the lagoon may be induced into the aquifer by pumpage from wells.

Outside the populated urban centers, aquifers may be recharged with surface water stored in dams. Releases could be made on a flexible basis, depending on weekly or monthly needs, in order to avoid losses resulting from use of a preset schedule. Location of well fields near stream channels would create cones of depression below the streambed, which would increase infiltration to a maximum. Downstream concessions could be satisfied by conveying water from the reservoir through canals. ' The canals could also be used to deliver water to the more permeable soils, as delineated on maps available from the U.S. Soil Conservation Service, to recharge the aquifer on an areal basis. Although this approach may have some application in Vieques, St. Croix, and St. Thomas, the main potential seems to be the South Coast province, Lajas Valley, and the North Coast province of Puerto Rico. In Puerto Rico, reservoirs would be located in the Interior province, and water would be conveyed by pipes, tunnels, or lined canals to infiltration areas located upgradient from pumpage centers. Presently, Puerto Rico has many reservoirs that could be utilized for artificial recharge, but these would have to be designated for such use.

\section{GROUND-WATER SALVAGE}

Enhancement of recharge to aquifers will make more water available to wells, but this practice can be supplemented by ground-water salvage measures. Ground water may be salvaged by extraction of water that would otherwise be lost as evapotranspiration or discharged to streams. Salvage can be accomplished by eliminating deep-rooted vegetation or lowering the water table to a depth at which evapotranspiration and loss to streams are minimized.

Ground-water salvage may have application in areas where the water table is close to the ground surface. The actual depth at which evapotranspiration losses can be minimized depends on local conditions. In Puerto Rico, evapotranspiration losses may be minimized by maintaining the water table below about $1.8 \mathrm{~m}$ where sugarcane is the predominate vegetation. At Cinnamon Bay in St. John, the roots of brush and trees have been observed to form a dense mat at the top of the water table at a depth of $6 \mathrm{~m}$ in alluvium (Cosner, 1972). In such case it may be practical to replace the deep-rooted vegetation.

During the process of water-table lowering, a major part of the pumpage would be supplied from storage, and well production may be relatively high. Once the water table has reached a point where further lowering does not contribute to any significant evapotranspiration reduction, well production would have to be reduced in order to attain a new equilibrium state. After this condition is attained, pumpage should not exceed the available recharge, or the process would be one of ground-water mining rather than salvage. Areas with greatest ground-water salvage potential are the West Coast and East Coast provinces in Puerto Rico and Turpentine Run Basin in St. Thomas. Studies have indicated that as much as $16.6 \mathrm{hm}^{3} / \mathrm{yr}$ could be salvaged in Yabucoa Valley (Robison and Anders, 1973); $8.7 \mathrm{hm}^{3} / \mathrm{yr}$ in Maunabo Valley (Adalphson and others, 1977); and about $0.25 \mathrm{hm}^{3} / \mathrm{yr}$, in the Turpentine Run Basin (Jordan and Cosner, 1973). Others means of salvaging ground water may require a change in land utilization. 
The largest area affected by seawater intrusion is the Caño Tiburones, a former marine slough covering an area of about 3,000 ha (pl. 2) on the north coast of Puerto Rico (Diaz, 1973). Water is pumped from the Caño Tiburones to drain the land for agriculture. The maintaining of water levels at or below sea level has resulted in seawater moving through the coastal ridge into the area. In 1970 , mean daily pumpage from the area was $5.1 \mathrm{~m}^{3} / \mathrm{s}\left(100 \mathrm{hm}^{3} / \mathrm{yr}\right)$ of saline water. The dissolvedsolids concentration of this water had the equivalent of a mixture of about 30 percent seawater and 70 percent freshwater (nearly all of which was ground water). As rainfall was excessive in 1970 , freshwater discharge to the sea was probably 10-20 percent greater than that in a year of average rainfall. Even in a year of average rainfall, however, the freshwater pumped to the sea is equivalent to the total ground water pumped for industrial, irrigation, and public supply from the northcoast aquifer.

If the water table is allowed to rise within the Caño Tiburones, the water gradient, which presently favors intrusion of seawater across the coastal ridge, could be reversed and maintained and still permit much of the ground water to be recovered by wells inland of the caño. Considering that commercial production of rice under irrigation is to be undertaken on the north coast, much of the caño could possibly be converted for such agricultural use.

\section{GROUND-WATER MINING}

Ground-water mining and the deliberate introduction of seawater intrusion may be justified for slightly to moderately saline-water aquifers and for freshwater stored under the ocean, as is probable within the artesian aquifer of the North Coast province of Puerto Rico.

Slightly to moderately saline water has been defined as water containing between 1,000 and $10,000 \mathrm{mg} / \mathrm{L}$ of total dissolved solids (Robinove and others, 1958). Within the Caribbean Region, with the exception of the Lajas Valley in Puerto Rico and central St. Croix in the Virgin Islands, the slightly to moderately saline water is contained in the transition zone from freshwater to seawater along the coasts. Diaz (1974) has defined this transition zone for the South Coast province of Puerto Rico as that in which the water has total dissolved solids between 2,000 and 10,000 mg/L (fig. 19).

Potential areas for utilization of saline water could be the South Coast province and Lajas Valley of Puerto Rico and central St. Croix, where alternate freshwater sources are scarce. Water from these aquifers may be diluted with better quality water, thus stretching the total freshwater supply, or it may be desalinated at less expense than seawater can be.

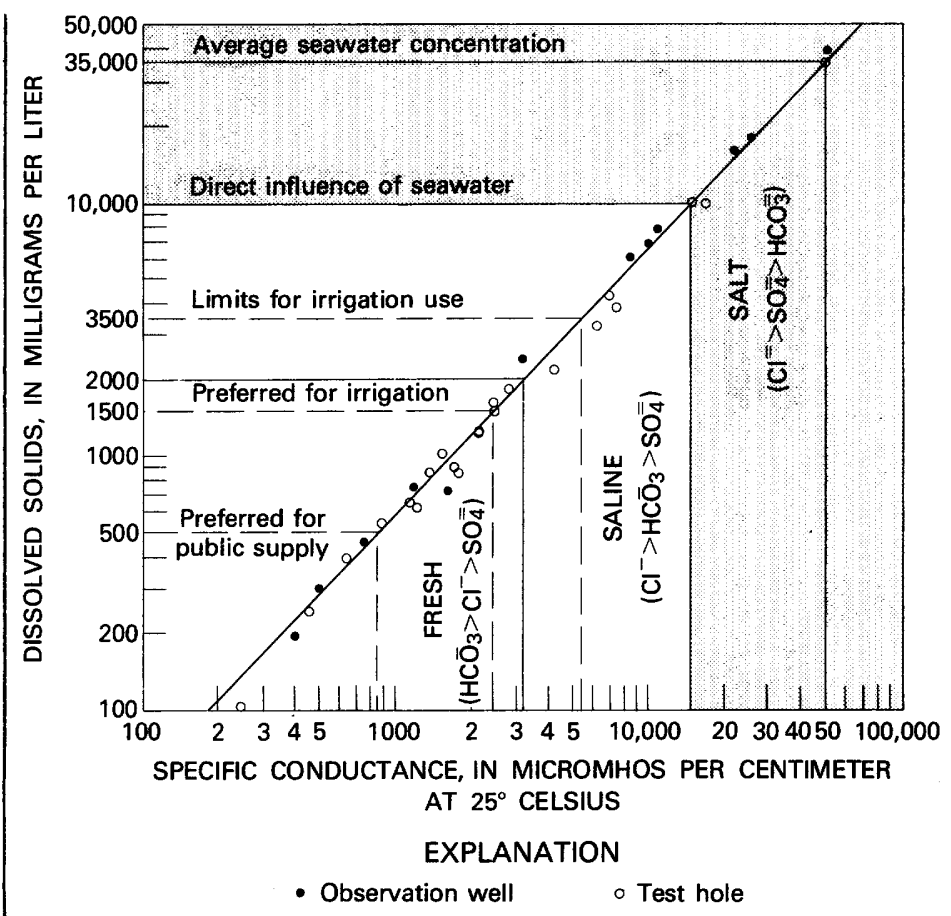

FIGURE 19. - Water classification of wells on the south coast of Puerto Rico (Diaz, 1974).

Ground-water mining may also be possible in the deep artesian aquifer in the North Coast province. Seaward of the coast it has been estimated that as much as 55,000 $\mathrm{hm}^{3}$ of freshwater may be stored in the confined zone (Black and Veatch, 1976).

\section{USE OF SEAWATER}

Seawater is another resource available in unlimited amounts in the Caribbean Region. It is used primarily for cooling purposes at powerplants and large industrial establishments. In the U.S. Virgin Islands, seawater has also been used for sanitation and firefighting in Charlotte Amalie, Christiansted, and Frederiksted. Further expansion of this dual system does not seem feasible economically when weighted against a waterreclamation and recycling system now being built on St. Croix (Black, Crow and Eidsness, 1976).

Two desalination units are under operation in Puerto Rico. One is operated by the Commonwealth Oil Refining Co. at Peñuelas on the south coast and has a rated capacity of $9,460 \mathrm{~m}^{3} / \mathrm{d}$; the other is operated by the Puerto Rico Aqueducts and Sewer Authority at Culebra and has a rated capacity of $110 \mathrm{~m}^{3} / \mathrm{d}$. In both areas, ground water remains the chief freshwater source. In the U.S. Virgin Islands the five desalination plants operated by the Virgin Islands Water and Power Authority have a total rated production capacity of 
$27,450 \mathrm{~m}^{3} / \mathrm{d}$. These units operate in conjunction with thermoelectric plants. Additional units proposed for the near future would increase total prouction to about $56,000 \mathrm{~m}^{3} / \mathrm{d}$. Other desalination plants are operated by heavy industries located in St. Croix and have a rated capacity totaling $15,000 \mathrm{~m}^{3} / \mathrm{d}$.

Desalinated seawater is extremely low in total dissolved solids and should be combined with other more mineralized water for public acceptance and for reducing corrosion of steel pipes and fittings used in the water-distribution system. This blending water is available from wells both in Culebra and in the U.S. Virgin Islands. Such an approach aids in stretching the total available water resource, but full optimization also requires implementation of a water-conservation program.

\section{CONSERVATION}

Only a limited amount of the total precipitation in an area may be used for beneficial purposes. Alternate water sources such as desalinated seawater, which could be considered undepletable in the Caribbean Region, are available but at high cost. Therefore, without an integrated water-conservation program involving all sectors of a community, optimization of the water resource is not possible.

Water conservation can be described as (1) using the lowest quality water compatible with purpose, (2) reducing water consumption, (3) reusing water, and (4) reducing contamination. The first two conservation practices listed are self-explanatory and in most areas are employed when the available resource is scarce. The latter two offer the greatest conservation benefits.

\section{WATER REUSE}

Water reuse has been undertaken in Puerto Rico by the establishment of Irrigation Districts, which obtain their flow from releases by hydroelectric plants. In other areas, water is used more than once, but the reuse occurs more by chance than according to plan. Waste effluents, especially from sewage-treatment plants, could be considered for integration into the overall plan for use of water resources within a basin. The quantity of treated sewage effluent discharged to sea in Puerto Rico may be about $487,000 \mathrm{~m}^{3} / \mathrm{d}$, of which about $73,000 \mathrm{~m}^{3} / \mathrm{d}$ is discharged from the water-deficient South Coast province. In the U.S. Virgin Islands, about $12,000 \mathrm{~m}^{3} / \mathrm{d}$ of sewage is discharged to sea, excluding that from seawater systems.

The U.S. Virgin Islands were the first in the Caribbean Region to investigate the feasibility of reclaiming sewage effluent. Pilot studies, begun in 1974, have shown that use of spreading basins to augment the yield of wells is generally feasible in alluvual aquifers, but not in the marl formations, such as those found at Golden Grove, St. Croix (Buros, 1976). Spreading basins may be feasible, however, at Barren Spot, St. Croix (Jordan, 1975); the cost of treating the sewage effluent, surface spreading, and final pumping of the percolated water at wells was about $\$ 0.57$ per cubic meter at St. Croix (in 1974). This cost compared favorably with that for water produced by the Water and Power Authority at desalination plants, which was $\$ 1.36$ per cubic meter (in 1974). Full scale application of this recharge technique on St. Croix and its integration with the overall water resources are discussed in detail by Buros (Black, Crow, and Eidsness, 1976).

Water-reclamation studies were initiated on an experimental basis in Puerto Rico in 1976. Sewagetreatment-plant effluent is being utilized for the irrigation of small plots of sugercane and grass at Fort Allen, near Ponce in the South Coast province. Preliminary findings indicate that such a procedure is feasible, but additional investigations are warranted to determine the feasibility of applying secondary treated sewage effluent for irrigation of sugarcane on a larger scale. This application would somewhat relieve the present stress on the aquifer and make ground water available for industrial purposes and public supply.

Among the factors that must be considered in a waterreclamation program intended for recharge or irrigation are the long-term increase of dissolved solids in ground waters and the accumulation of salts in soils. These factors are critical owing to the high potential evapotranspiration, which ranges from $1,850 \mathrm{~mm}$ to $2,070 \mathrm{~mm}$ per year in the areas of greatest water deficiency and where water reclamation practices are most urgently needed. Under this physical limitation, recharge in the U.S. Virgin Islands should be conducted using waste effluents low in dissolved solids. This condition would probably require dividing each island into two zones: one where water is mainly derived from desalination plants (low in dissolved solids) and waste effluents recharged, and the second where waters supplied are higher in dissolved solids and no attempt at recharging is made (Black, Crow and Eidsness, 1976). On Vieques a water-reclamation program could be initiated as soon as water from Puerto Rico becomes available.

In the South Coast province an extensive irrigation system already exists (Canal de Guamaní, Canal de Patillas, and Canal de Juana Díaz). If a regional sewageeffluent reclamation program is established in the near future and this effluent can be used for irrigation, the canals could probably be utilized for its distribution. This would make the better quality water from the reservoirs available for ground-water recharge in the more favorable areas. In general, the best recharge zones are 
located in the apexes of alluvial fans (fig. 10), where stream channels can serve for distribution.

Reclaimed waste water could also be used for injection at wells situated parallel to the coast in order to control seawater intrusion and enhance ground-water-salvage operations.

\section{REDUCING CONTAMINATION (SUBSURFACE STORAGE)}

Federal and state regulations have established maximum tolerable limits on the concentration of pollutants permitted in effluents, streams, and coastal zones. For most wastes the treatment technology is available to comply with these standards. In many processes, however, the ultimate treatment consists of concentrating the pollutants and discarding these at sea or in landfills. A possible alternate approach to this wastehandling problem could be subsurface disposal by deepwell injection. This alternative has been a practice of long standing by petroleum companies in the United States for disposal of brines that would otherwise contaminate beneficial surface- or ground-water sources. The technique was investigated and adopted by a number of other industries in the late 1960 's, and by 1974 there were 333 authorized injection wells in the United States, not including the thousands utilized for brine disposal by the petroleum industry (Walker and Cox, 1976). Most of the nonbrine injection wells are utilized for disposal of toxic wastes produced by chemical, petrochemical, and pharmaceutical companies.

Disposal of wastes in the subsurface is based on the concept that liquid wastes can be injected and confined within geologic strata not having other actual or potential beneficial uses. An acceptable geologic formation must (1) have the capacity to accept injected wastes at a reasonable rate and under reasonable pressures without adverse response, (2) not contain any valuable resources that would be destroyed by injection, (3) be physically and chemically compatible to injected wastes, and (4) have adequate confining conditions. Of these prerequisites the last is probably the most difficult to determine and is the focus of much controversy.

Adverse effects of waste injection into mineralized ground waters for which society has no present or anticipated use are difficult to predict. The possibliity that environmental degradation may occur as a result of unexpected problems exists primarily because of imperfect knowledge concerning the physical system involved. Injected wastes may not remain within the stipulated zone and may escape through an undiscovered break in the confining zone. This break may be either a natural discontinuity or a product of the injection stress. Such leaks may not be detected due to the high cost of monitoring wells and the limited number of checkpoints that can be established. The impact of leakage may be detected only after it has affected a usable resource.

In general, criteria for establishing injection wells should be no less stringent than the policy statement adopted by the U.S. Environmental Protection Agency (EPA). The stated objectives of EPA injection-well policy (Walker and Cox, 1976) are to (1) protect the subsurface from pollution or other environmental hazards attributable to improper injection or ill-sited injection wells, (2) ensure that engineering and geological safeguards adequate to protect the integrity of the subsurface environment are adhered to in the preliminary investigation, design, construction, operation, monitoring, and abandonment phases of injection-well projects, and (3) encourage development of alternative means of disposal that afford greater environmental protection.

In the Caribbean Region, various localities are underlain by sedimentary deposits several thousand feet thick. Data are lacking, however, on the physical properties of the geologic formations and their capacity to accept wastes. Areas that may merit investigation for their waste-injection potential exist in the North Coast and the South Coast provinces of Puerto Rico.

The only waste-injection wells in Caribbean Region are two wells drilled into the Lares Formation in the North Coast province near Barceloneta.

\section{INFORMATION DEFICIENCIES}

Future effective management of ground-water resources will depend greatly on the availability and accuracy of field data and their application in model simulations of aquifers. Some of the information required for models, such as well logs, pumpage, and basin diversions, can be stored in a computerized data bank and be available to all public and private institutions involved in water management and planning. Under present conditions, water-balance studies are largely based on estimated values. Aquifer models are usually prepared with estimated values for mean hydraulic conductivity and storage coefficient, as well as assumed boundary conditions, which can give good approximations to one given set of stress conditions but can deviate considerably under others. It may be beneficial to construct a model of an aquifer, however, even though a very limited amount of data are available. The results obtained in such preliminary trials will at least indicate where and what type of data are needed for effective management of the available water resource.

All aquifer-simulation models require at least one or more years of water-level data. It is therefore urgent that monitoring networks be established for all aquifers, 
even though ground-water development may be minimal in some areas. Within aquifers for which preliminary areal models have been constructed, monitoring networks should be maintained to determine whether or not conditions follow those predicted. If significant deviation is detected, the cause can be evaluated and remedial measures can be taken as appropriate.

Among the most important needs for improving the knowledge about aquifers in the Caribbean Region are listed as follows:

1. Better definition of conditions within the two major aquifers: knowledge needed about the following:

a. Hydrologic relationship between bedrock and alluvium in the South Coast province of Puerto Rico and stream-aquifer interrelationships

b. Extent of the artesian system in the North Coast province of Puerto Rico

c. Ground-water flow within the North Coast province west of Arecibo

2. Areal studies made concerning the following:

a. Ground-water flow system in Lajas Valley

b. Water-balance for unstudied aquifers in the East Coast, West Coast, and Interior provinces

c. Water-table monitoring throughout Puerto Rico, the offshore islands, and U.S Virgin Islands

d. Qualitative and quantitive assessment of salinewater reserves of St. Croix and in the coastal aquifers of Puerto Rico

e. Chemical-quality data to assess the extent of contamination and seawater intrusion

Besides these basic needs, research is also lacking on evapotranspiration and its relationship to soils and vegetation under the climatic conditions in the Caribbean Region. At present it is unknown if under longterm conditions thick vegetation and plant debris aid ground-water recharge by reducing runoff, enhancing infiltration, and reducing direct evaporation of rainfall or whether they use more water from the soil through transpiration. Archaeological sites, surface features, and historical notes indicate that water was much more plentiful at now parched areas in Puerto Rico's offshore islands and in the U.S. Virgin Islands.

\section{SUMMARY}

The Caribbean Region consists of the Commonwealth of Puerto Rico $\left(8,990 \mathrm{~km}^{2}\right)$ and the U.S. Virgin Islands $\left(350 \mathrm{~km}^{2}\right)$. It is among the most densely populated areas in the world, with an overall population of approximately $3,200,000$ people. Within the past 25 years the islands have undergone a rapid transformation from an agriculturally based economy to one dependent on industrial development, tourism, and related services.

Water is among the most abundant and valuable natural resources in the Caribbean Region, but its availability varies significantly in both space and time. Rainfall contributes an annual average of $1,800 \mathrm{~mm}$ in Puerto Rico and $1,060 \mathrm{~mm}$ in the U.S. Virgin Islands. Of this amount, 1,130 mm (or 64 percent) in Puerto Rico and $990 \mathrm{~mm}$ (or 93 percent) in the U.S. Virgin Islands is lost to evapotranspiration. The water available for use in liquid form amounts to about $5,400 \mathrm{hm}^{3} / \mathrm{yr}$ in Puerto Rico and $24 \mathrm{hm}^{3} / \mathrm{yr}$ in the U.S. Virgin Islands. These amounts would theoretically satisfy the total water needs of both areas, which are about $919 \mathrm{hm}^{3} / \mathrm{yr}$ and 20 $\mathrm{hm}^{3} / \mathrm{yr}$, respectively (1975). In reality, most of this flow is contributed by intensive rainstorms and is lost to the ocean as runoff. Potential for retaining a large part of this flow exists on the island of Puerto Rico, but presently the total usable reservoir storage capacity is only about $230 \mathrm{hm}^{3}$. In the U.S. Virgin Islands, small dams and ponds have a storage capacity of about $2 \mathrm{hm}^{3}$.

Aquifers constitute a valuable water resource in the Caribbean Region. In Puerto Rico, ground-water withdrawals provide about 38 percent of the total water requirements, whereas in the U.S. Virgin Islands, they provide 10 percent. Excluding desalinated-water supplies in the U.S. Virgin Islands, ground water provides about 72 percent of the freshwater used. Of the 350 $\mathrm{hm}^{3} / \mathrm{yr}$ ground-water withdrawal in Puerto Rico, irrigation uses 53 percent; industry, 29 percent; and public water supply, 18 percent. In the U.S. Virgin Islands, ground water is withdrawn about equally from private wells and public water-supply wells. Based on past trends and future economic outlook in the region, estimates are that by 1985 ground-water pumpage in Puerto Rico will be about $426 \mathrm{hm}^{3} / \mathrm{yr}$ and in the U.S. Virgin Islands, about $4.5 \mathrm{hm}^{3} / \mathrm{yr}$. This withdrawal is the estimated maximum sustained yield of all aquifers in the U.S. Virgin Islands under natural-recharge conditions.

Most large-scale ground-water developments in Puerto Rico are in the North Coast and South Coast provinces. The North Coast province contains the island's most productive aquifer, which has been undergoing rapid development for industrial water supply since 1968 , when a major artesian system was tapped. The extent of this artesian system is unknown, but it has been tapped within the lower part of the Cibao Formation (Montebello Limestone Member) and in the upper part of the Lares Limestone. The South Coast province aquifer consists of deep alluvial deposits. It has been extensively developed for irrigation of sugarcane and for industrial water supply. Unlike the north-coast aquifer system, which has large untapped resources, this aquifer 
will support only minor future development if effective management practices are not introduced.

In the U.S. Virgin Islands, the most extensive aquifer is the fragmented igneous rock. It contributes little water to wells, but weighed against the costs of desalinated water, its exploitation is feasible for supplementing domestic water needs. The most productive aquifer consists of marl and alluvium deposits in central St. Croix. Although this aquifer contributes less than 6.3 $\mathrm{L} / \mathrm{s}$ to individual wells, it yields about $0.86 \mathrm{hm}^{3} / \mathrm{yr}$ to public water-supply wells and about $0.54 \mathrm{hm}^{3} / \mathrm{yr}$ to private wells. Future development of this aquifer could probably produce an additional $1.0 \mathrm{hm}^{3} / \mathrm{yr}$.

Ground-water resources will continue to play an important role in the future development of both Puerto Rico and the U.S. Virgin Islands. In order to meet future needs, it is necessary that hydrologic principles be effectively applied in managing the total water resource.

Optimization of the water resources can be accomplished through conjunctive use of surface and ground waters and through conservation practices. Optimal use may involve artificial recharge, ground-water salvage, saline- or fresh-ground-water mining, use of seawater, waste-water reuse, and use of underground space for temporary storage of wastes, which could otherwise contaminate valuable water supplies.

Efficient development of the water resources within a basin also requires a thorough knowledge of the relationship that exists between surface and subsurface water. Among the most urgent needs in the Caribbean Region is a computerized data bank containing information on ground-water withdrawal, consumptive use, surface diversions, and such other flows necessary for water-budget estimates. These data can be used with the available knowledge of the aquifers to construct digital or analog models. Such an approach would serve to point out areas where new information is needed, aid in assigning investigation priorities, and contribute to effective management of the total water resource.

\section{SELECTED REFERENCES}

Acevedo, G., Lugo-Lopez, M. A., and Ortiz-Velez, J., 1959, Occurrence of soil tumors northeast of the Guanica Lagoon, Lajas Valley, Puerto Rico: University of Puerto Rico Agricultural Station Journal, v. 43, no. 2, p. 103-115.

Adolphson, D. G., Seijo, M. A., and Robinson, T. M., 1977, Water resources of Maunabo Valley, Puerto Rico: U.S. Geological Survey Water-Resources Investigations 76-115, $44 \mathrm{p}$.

Anders, R. B., 1968, Reconnaissance of the water resources of the Central Guanajibo Valley, Cabo Rojo, Puerto Rico: U.S. Geological Survey open-file report, $18 \mathrm{p}$.

Anderson, 1976, Ground water in the San Juan metropolitan area, Puerto Rico: U.S. Geological Survey Water-Resources Investigation $41-75,34 \mathrm{p}$.
1977, Ground water in the Lajas Valley, Puerto Rico: U.S. Geological Survey Water-Resources Investigation 68-76, 45 p.

Arnow, T., and Crooks, J. W., 1960, Public Water supply in Puerto Rico: Commonwealth of Puerto Rico Water-Resources Bulletin 2, $34 \mathrm{p}$.

Bennett, G. D., 1972, Ground water along Rio Bucana at Ponce, Puerto Rico, and effects of a proposed floodway on ground-water quality: Commonwealth of Puerto Rico Water-Resources Bulletin 11, 28 p.

_ 1976, Electrical analog simulation of the aquifers along the south coast of Puerto Rico: U.S. Geological Survey Open-File Report 76-4, $101 \mathrm{p}$.

Bennett, G. D., and Giusti, E. V., 1972, Ground water in the Tortuguero area, Puerto Rico, as related to proposed harbor construction: Commonwealth of Puerto Rico Water-Resources Bulletin 10, $25 \mathrm{p}$.

Black, Crow and Eidsness, 1976, A water management plan for St. Croix, U.S. Virgin Islands: Black, Crow and Eidsness, Inc., Consulting Engineers, Gainsville, Fl.

Black and Veatch, 1976, Water supply study for entire island of Puerto Rico, first phase: Black and Veatch Consulting Engineers, Kansas City, Miss.

Black and Veatch, Domenech, R. A., and Associates, 1970, Water resources of Puerto Rico, phase II, Ground Water appraisal: Black and Veatch Consulting Engineers, Kansas City, Miss., and R. A. Domenech and Associates, Hato Rey, Puerto Rico.

Bogart, D. B., Arnow, T., and Crooks, J. W., 1964, Water resources of Puerto Rico, a progress report: Commonwealth of Puerto Rico Water-Resources Bulletin 4, $102 \mathrm{p}$.

Bonnett, J. A., and Brenes, E. J., 1958, Detailed salinity survey of Lajas Valley: University of Puerto Rico Agricultural Experimental Station Bulletin 111, 114 p.

Briggs, R. P., and Akers, J. P., 1965, Hydrogeologic map of Puerto Rico and adjacent islands: U.S. Geological Survey Hydrologic Investigations Atlas HA-197, scale 1:240,000.

Briggs, R. P., and Seiders, V. M., 1972, Geologic map of the Isla de Mona Quadrangle, Puerto Rico: U.S. Geological Survey Miscellaneous Geologic Investigations Map I-718, scale 1:20,000.

Buros, O. K., 1976, Wastewater reclamation project, St. Croix, U.S. Virgin Islands: U.S. Environmental Protection Agency, Environmental Protection Technology Series EPA-600/2-76-134, $244 \mathrm{p}$.

Calvesbert, R. J., 1970, Climate of Puerto Rico and U.S. Virgin Islands: U.S. Department of Commerce Environmental Science Services Administrative Publication 60-52, Silver Spring, Md., 29 p.

Cederstrom, D. J., 1950, Geology and ground-water resources of St. Croix, Virgin Islands: U.S. Geological Survey Water-Supply Paper 1067, 117 p.

Cosner, O. J., 1972, Water in St. John, U.S. Virgin Islands: U.S. Geological Survey open-file report, $46 \mathrm{p}$.

Crooks, J. W., Grossman, I. G., and Bogart, D. B., 1968, Water resources of the Guayanilla-Yauco area, Puerto Rico: Commonwealth of Puerto Rico Water-Resources Bulletin 5, $55 \mathrm{p}$.

Diaz, J. R., 1968-1974, Ground water levels in the south coast of Puerto Rico (Guanica to Patillas): U.S. Geological Survey Data Release PR-1, San Juan, P.R.

1973, Chemical quality of water in Caño Tiburones, Puerto Rico, A reconnaissance study carried out in 1967: U.S. Geological Survey open-file report (map), $2 \mathrm{p}$.

1974, Coastal salinity reconnaissance and monitoring system-south coast of Puerto Rico: U.S. Geological Survey OpenFile Report 74-1, 28 p. 
Donnelly, T. W., 1960, The geology of St. Thomas and St. John, Virgin Islands, in Caribbean Geological Conference, 2d, Mayagüez, P.R., January 4-9, 1959, Transactions: p. 153-155.

-1966 , Geology of St. Thomas and St. John, U.S. Virgin Islands, in Hess, H.H., ed., Caribbean Geological Investigations: Geological Society of America Memoir 98, p. 85-176.

Giusti, E. V., 1968, Water resources of the Juana Diaz area, Puerto Rico, a preliminary appraisal, 1966; Commonwealth of Puerto Rico Water-Resources Bulletin 8, $43 \mathrm{p}$.

-1971, Water resources of the Coamo area, Puerto Rico: Commonwealth of Puerto Rico Water-Resources Bulletin 9, $31 \mathrm{p}$.

1978, Hydrogeology of the karst of Puerto Rico: U.S. Geological

Survey Professional Paper 1012, 68 p.

Giusti, E. V., and Bennett, G. D., 1976, Water resources of the northcoast limestone area, Puerto Rico: U.S. Geological Survey WaterResources Investigation 42-75, $42 \mathrm{p}$.

Giusti, E. V., and Lopez, M. A., 1967, Climate and streamflow in Puerto Rico: Caribbean Journal of Science v. 7, nos. 3-4, p. 87-93.

Grossman, I. G., Bogart, D. B., Crooks, J. W., and Díaz, J. R., 1972, Water resources of the Talloboa Valley, Puerto Rico: Commonwealth of Puerto Rico Water-Resources Bulletin 7, 115 p.

Heisel, J. E., and González, J. R., 1976, Ground water levels on the south coast of Puerto Rico: U.S. Geological Survey Open-File Report PR-76-705, 13 p.

Jordan, D. G., 1973, A summary of actual and potential water resources, Isla de Mona, Puerto Rico, in Puerto Rico Environmental Quality Board, Mona and Monito Islands, an assessment of their natural and historical resources: Volume 2, p. D1-D8.

-1975 , A survey of the water resources of St. Croix, Virgin Islands: U.S. Geological Survey open-file report, $51 \mathrm{p}$.

Jordan, D. G., and Cosner, O. J., 1973, A survey of the water resources of St. Thomas, Virgin Islands: U.S. Geological Survey open-file report, $55 \mathrm{p}$.

Jordan, D. G., and Gilbert, B. K., 1976, Water supply and waste disposal, Culebra, Puerto Rico: U.S. Geological Survey WaterResources Investigation 3-76, $31 \mathrm{p}$.

Kaye, C. A., 1959, Geology of the San Juan metropolitan area, Puerto Rico: U.S. Geological Survey Professional Paper 317-A, 48 p.

Kipple, F. P., and others, 1968, Water records of Puerto Rico 1958-63: U.S. Geological Survey Data Report, $353 \mathrm{p}$.

McClymonds, N. E., 1967, Water resources of the Guanica area, Puerto Rico, a preliminary appraisal, 1963: Commonwealth of Puerto Rico Water-Resources Bulletin 6, $43 \mathrm{p}$.

1972, Water resources of the Ponce area, Puerto Rico: Commonwealth of Puerto Rico Water-Resources Bulletin 14, $26 \mathrm{p}$.

McClymonds, N. E., and Diaz, J. R., 1972, Water resources of the Jobos area, Puerto Rico, a preliminary appraisal, 1962: Commonwealth of Puerto Rico Water-Resources Bulletin 13, $32 \mathrm{p}$.

McGuinness, C. L., 1948, Ground water resources of Puerto Rico: Puerto Rico Aqueduct and Sewer Service, $613 \mathrm{p}$.
Mattson, P. H., 1960, Geology of the Mayaguez area, Puerto Rico: Bulletin of the Geological Society of America, Vol. 71, p 319-362.

Meyerhoff, H. A., 1933, Geology of Puerto Rico: Puerto Rico University Monograph Series B, Physical and Biological Sciences, no. 1, $306 \mathrm{p}$.

Morris, Greg, 1975, 1976, Water resources assessment technical memorandums two and three, Caribbean Region: Puerto Rico Department of Natural Resources, $390 \mathrm{p}$.

National Academy of Sciences, National Academy of Engineering, 1974, Water Quality Criteria, 1972: U.S. Environmental Protection Agency R3-73-003, 594 p.

Puerto Rico Planning Board, 1976, Statistical yearbook, Puerto Rico 1974: $234 \mathrm{p}$.

Puerto Rico Water Resources Authority, 1975, Preliminary analysis report north-coast nuclear plant: v. 12 , no. 1 , sect. $2.5-215 \mathrm{~B}$, amend. 26.

Robinove, C. J., Langford, R. H., and Brookhart, J. W., 1958, Salinewater resources of North Dakota: U.S. Geological Survey WaterSupply Paper 1428, 72 p.

Robison, T. M., 1972, Ground water in central St. Croix, U.S. Virgin Islands: U.S. Geological Survey open-file report, $18 \mathrm{p}$.

Robison, T. M., and Anders, R. B., 1973, Electrical analog model study of the alluvial aquifer in the Yabucoa Valley, Puerto Rico, Phase 2-the planning, construction, and use of the model: U.S. Geological Survey Open-File Report 73-1, 22 p.

Robison, T. M., and others, 1973, Water records of the U.S. Virgin Islands, 1962-69: U.S. Geological Survey Data Report, 163 p.

Slodowski, T. R., 1958, Geology of the Yauco area, Puerto Rico [abs, Princeton University Ph.D. dissertation]: Dissertation Abstracts, v. 18 , no. 1, 200 p.

U.S. Geological Survey, 1968-72, Water resources data for Puerto Rico, Part 3-Groundwater records: U.S. Geological Survey Data Report, $78 \mathrm{p}$.

Vazquez, R., and Ortiz-Valez, J., 1967, Drainage and ground-water research in Lajas Valley, Puerto Rico: University of Puerto Rico Agricultural Experiment Station Bulletin 206, 36 p.

Walker, W. R., and Cox, W. E., 1976, Deep well injection of industrial wastes-government controls and legal constraints: Virginia Water Resources Research Center, Blacksburg, Va., 163 p.

Ward, P. E., and Truxes, L. S., 1964, Water wells in Puerto Rico: Commonwealth of Puerto Rico Water-Resources Bulletin 3, 248 p.

Whetten, J. T., 1966, Geology of St. Croix, U.S. Virgin Islands: Geological Society of America Memoir 98, p. 177-239.

Willardson, L. S., 1958, Lajas Valley drainage problems: University of Puerto Rico Agricultural Experiment Station Bulletin 143, $64 \mathrm{p}$.

Zapp, A. D., Berquist, H. R., and Thomas, C. R., 1948, Tertiary geology of the coastal plains of Puerto Rico: U.S. Geological Survey Oil and Gas Investigation preliminary map 85, scale 1:60,000. 


\section{Summary Appraisals of the}

Nation's Ground-Water Resources

GE OL O G I A L S UR VEY PROFESSIONALA PAPER 813

This volume was published as separate chapters $A-U$

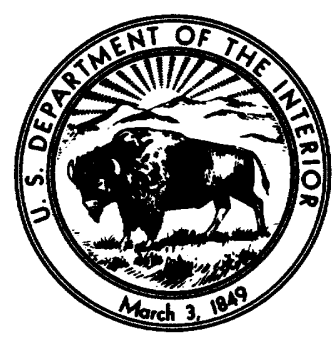


UNITED STATES DEPARTMENT OF THE INTERIOR

CECIL D. ANDRUS, Secretary

\section{GEOLOGICAL SURVEY}

H. William Menard, Director 


\section{CONTENTS}

[Letters designate the chapters]

(A) Summary appraisals of the nation's ground-water resources-Ohio Region, by R. M. Boyd, Jr.

(B) Summary appraisals of the nation's ground-water resources-Upper Mississippi Region, by R. M. Boyd, Jr.

(C) Summary appraisals of the nation's ground-water resources-Upper Colorado Region, by Don Price and Ted Arnow.

(D) Summary appraisals of the nation's ground-water resources-Rio Grande Region, by S. W. West and W. L. Broadhurst.

(E) Summary appraisals of the nation's ground-water resources-California Region, by H. E. Thomas and D. A. Phoenix.

(F) Summary appraisals of the nation's ground-water resources-Texas-Gulf Region by E. T. Baker, Jr. and J. R. Wall.

(G) Summary appraisals of the nation's ground-water resources-Great Basin Region, by Thomas E. Eakin, Don Price, and J. R. Harrill.

(H) Summary appraisals of the nation's ground-water resources-Arkansas-White-Red Region, by M. S. Bedinger and R. T. Sniegocki.

(I) Summary appraisals of the nation's ground-water resources-Mid-Atlantic Region, by Allen Sinnott and Elliott M. Cushing.

(J) Summary appraisals of the nation's ground-water resources-Great Lakes Region, by William G. Weist, Jr.

(K) Summary appraisals of the nation's ground-water resources-Souris-Red-Rainy Region, by Harold O. Reeder.

(L) Summary appraisals of the nation's ground-water resources-Tennessee Region, by Ann Zurawski.

(M) Summary appraisals of the nation's ground-water resources-Hawaii Region, by K. J. Takasaki.

(N) Summary appraisals of the nation's ground-water resources-Lower Mississippi Region, by J. E. Terry and C. T. Bryant.

(O) Summary appraisals of the nation's ground-water resources-South Atlantic-Gulf Region, by D. J. Cederstrom, E. H. Boswell, and G. R. Tarver.

(P) Summary appraisals of the nation's ground-water resources-Alaska, by Chester Zenone and Gary S. Anderson.

(Q) Summary appraisals of the nation's ground-water resources-Missouri Basin Region, by O. James Taylor.

(R) Summary appraisals of the nation's ground-water resources-Lower Colorado Region, by E. S. Davidson.

(S) Summary appraisals of the nation's ground-water resources-Pacific Northwest Region, by Bruce L. Foxworthy.

(T) Summary appraisals of the nation's ground-water resources-New England Region, by Allen Sinnott.

(U) Summary appraisals of the nation's ground-water resources-Caribbean Region, by Fernando Gómez-Gómez and James E. Heisel. 


\section{•}


$\therefore$ 